\title{
PELOS CAMINHOS DA CIDADE: \\ EXPERIÊNCIAS DE PAISAGENS DA AMAZÔNIA URBANA EM \\ VIDEOCLIPES
}

\author{
Victoria Costa $^{1}$
}

\section{Introdução}

As paisagens de Belém do Pará são campo a ser olhado com mais atenção, principalmente por quem (con)vive nelas. No centro da cidade, prédios enormes, muitos ainda em construção, empreendimentos, grandes lojas, restaurantes, vitrines. Alguns (poucos) pontos, como a turística Estação das Docas, Portal da Amazônia ou Ver-oPeso, têm a vista para a Baía do Guajará. Na Cidade Velha, bairro do começo da fundação da cidade, ainda é possível olhar para cima e ver o que restou de casarões antigos, arquiteturas que remetem à estruturas europeias, enquanto os pisos térreos foram ocupados por pontos comerciais. Nos bairros considerados periféricos há variedade de perfis, sejam as casas cujas saídas são diretamente na lama, palafitas ou ruas sem asfalto, sejam os grandes condomínios e prédios planejados que estão surgindo em áreas mais afastadas, levando consigo serviços e produtos que ressignificam estas vizinhanças e diluindo, aos poucos, algumas noções de centro.

Como é possível notar, apenas na Região Metropolitana de Belém (RMB) já existem múltiplos espaços passíveis de pesquisa e nenhum deles chega tão perto da visão exótica de cidade amazônica que é comumente ativada ao se referir a esta localidade. A imagem da Amazônia como ainda é amplamente conhecida hoje, começou a ser formada/criada quando da chegada dos europeus, a partir da sua surpresa com o diferente, com suas percepções sobre pessoas, costumes, locais que caracterizavam um "outro" distante não apenas geográfica, mas também culturalmente, em ambientes díspares do que estavam acostumados, de natureza exuberante. É deste ponto que inicia-se esta pesquisa. Quais Beléns estão sendo mostradas e vistas? Enquanto Amazônia, quais as percepções que hoje criamos, divulgamos e incitamos sobre o espaço, a cotidianidade e sobre nós, habitantes?

Neste artigo, por meio do audiovisual, mais especificamente o videoclipe, aprofundarei por um detido recorte de seis produções belenenses a fim de reunir

\footnotetext{
${ }^{1}$ Universidade Federal do Pará, Brasil. Email: victoriaetcosta@gmail.com

ORCID id: http://orcid.org/0000-0002-2463-9621
} 
percepções de habitantes da cidade sobre o que é filmado, principalmente por quem tem o convívio cotidiano com estes espaços citadinos, que fogem ao imaginário comum sobre capitais da região. Ao conversar com músicos, diretores e transeuntes das ruas filmadas, é possível notar o quão diversa pode ser uma mesma paisagem, imagem ou um recorte. A vivência do e no espaço faz toda a diferença diante do ponto que se discute. Assim, desvela-se a importância de entender como belenenses notam a si e seu cotidiano e como reproduzem isto, como é transferido para produções artísticas, contribuindo também na formação de percepções de quem desconhece a cidade. Proponho observarmos nosso (aqui enquanto belenenses, nortistas, amazônidas, e me incluo) papel enquanto autores, afirmadores, disseminadores das imagens criadas sobre nós mesmos.

A experiência da cidade amazônida figura como o ponto principal desta pesquisa. Sustento a ideia que é possível não somente transferirmos nossas vivências para um produto artístico, como também recriar, através do vídeo, as percepções de quem consome. Assim, tornando possível a reformulação do que se entende enquanto uma cidade na e da Amazônia, refletindo em inúmeros âmbitos sociais, históricos e políticos da região.

\section{Arte, antropologia e seus entremeios}

O registro, a vivência, o discurso criado sobre um lugar pode ser feito de maneiras particulares e diversas. Há pouco mais de 100 anos a antropologia investiga diferentes formas de viver, observa grupos com costumes diversos e os registra, investiga e documenta. Desde os tempos das grandes embarcações (que remetem aos séculos XV e XVI, no caso das Américas) a Amazônia foi e segue sendo retratada a partir de sua dita exuberância natural. Suas florestas, rios e pessoas são os traços primeiros quando se fala da região ainda hoje em dia, figurando o que Michael Rogin chama de "excesso de valor simbólico" 2 , que torna as identidades rasas, a partir de caricaturas ou figuras repetitivas, e que George Marcus (1991) diz operar enquanto marcador da identidade de um povo. Esta exotização da Amazônia como unidade achata a pluralidade de características existentes dentro desta enorme área e influi diretamente sobre as percepções geradas acerca da região.

Os discursos e linguagens utilizados para a disseminação desta Amazônia

\footnotetext{
${ }^{2}$ Ver mais sobre em "Blackface, White Noise", Michael Rogin, 1996.
} 
"exótica" ainda se perpetuam. Por conta disto, a preocupação primeira deste artigo, que é fruto da minha pesquisa de dissertação ${ }^{3}$, é discutir este estrangeirismo, este olhar de fora, e atentar para e a partir de quem é de dentro. Já foi brevemente falado como a Amazônia é retratada por quem a desconhece, mas como a retratam seus próprios habitantes? Assim, enveredo pela arte como uma das tantas formas de demonstrar estes olhares sobre espaços, pessoas e contextos. As consequências de apresentar, cada vez mais com propriedade, uma faceta dessa Amazônia (ainda desconhecida) podem levar a reconhecimentos sem precedentes, que acredito irem desde o trato sobre os temas e com habitantes locais, às políticas públicas baseadas em vivências concretas. Aquilo que é produzido no campo da arte reflete não somente a individualidade de quem cria, mas também o que é visto, vivido, pensado e sentido no âmbito coletivo. A arte é uma forma de expressão, independente da sua intencionalidade e da interpretação sobre a mesma. Para Bakhtin:

\begin{abstract}
A arte é inegavelmente social não porque representa o real, mas porque constitui uma "enunciação" situada historicamente - uma rede de signos endereçados por um sujeito ou sujeitos constituídos historicamente para outros sujeitos constituídos socialmente, todos imersos as circunstâncias históricas e nas contingências sociais. (Bakhtin apud Shohat; Stam, 2006: 265)
\end{abstract}

A partir desta fala de Bakhtin, vemos como o quê nos constitui, seja como indivíduos, seja como sociedade, implica diretamente no modo como criamos ou fruímos uma obra artística, pois carregam sentidos ou relações que são particulares a um grupo ou contexto. Elementos visuais, sabores, sotaques que podem, sim, ter sua apreensão por parte de quem desconhece estes códigos, mas se torna mais complexo quando há um diálogo maior entre o que se vive e o que se cria ou consome, quando se compartilha dos mesmos símbolos para haver compreensão:

É possível mostrar de forma razoável que muito do que os membros de um determinado grupo consideram como dados naturais é meramente um reflexo de seus próprios pressupostos. Essas pessoas, contudo, bem como qualquer um de nós, necessariamente agem e reagem de acordo com sua percepção do mundo, impregnando-o com o resultado de suas próprias construções. A realidade de todas as pessoas é composta de construções culturais, sustentadas de modo eficaz tanto pelo mútuo consentimento quanto por causas materiais inevitáveis. Este consentimento, ao que tudo indica, está incrustado em representações coletivas: a linguagem, as categorias, os símbolos, os rituais e as instituições. (Barth, 2000: 111)

\footnotetext{
${ }^{3}$ Costa, Victória Ester T. Pelos caminhos da cidade: experiência e percepção de paisagens em videoclipes na Amazônia contemporânea. Dissertação de mestrado. Antropologia. UFPA, 2019.
} 
São estas percepções ditas por Barth, construídas nos cotidianos e presentes nas "representações coletivas" que interessam a nós, aquilo que é natural no meio do conviver. O modo que criamos e a forma que vemos estão impregnados com nossas construções, as percepções que, para um grupo, passam a ser naturais. E é isto que transferimos para a arte. Canclini diz que "Há uma mudança de objeto de estudo na estética contemporânea. Analisar a arte já não é analisar obras, mas as condições textuais e extratextuais, estéticas e sociais, em que a interação entre os membros do campo gera e renova o sentido" (2003, p. 151), assim, o intuito da pesquisa foi, através dos vídeos escolhidos, chegar aos indivíduos que os constituem, os que elaboraram e que influenciaram a criação de cada um. Deste modo, pode-se ter uma visão dos caminhos possíveis para entender como os contextos históricos e sociais influenciam diretamente nas percepções e, portanto, nas criações artísticas.

Nas fotografias de Luiz Braga, nas ficções de Edyr Augusto, nas performances de Berna Reale, nos filmes de Vicent Cecim, nas filosofias de Benedito Nunes, nas pinturas de Éder Oliveira, Belém e Amazônia já foram eternizadas a partir da expressividade artística de cada um. Arrisco dizer que suas formas de representar aquilo que se propunham foram resultado de um olhar mais detido na atenção, no aprofundarse, uma visão não de quem acabou de conhecer tais personagens, espaços ou realidades, mas quem nelas (con)vive, dispensando apresentações ou superficialidades, já que dialogam com o conhecido. Parto do princípio de que a vivência na cidade os expõe a uma gama de referências que, como disse Barth (2000), são naturais. Podem não vir através de uma temática voltada para a Amazônia, mas sua música, cores, traços, espaços ou modos de falar vão impregnar suas obras de algum modo. Afinal, arte é isto, esta transferência de elementos de várias fontes do artista para a obra.

Diante desta pluralidade artística sobre e no território paraense, escolhi, então, debruçar-me sobre os vídeos. Com formação em comunicação social e, também, em cinema e audiovisual, trouxe para a antropologia minha proximidade com o vídeo para observar a capital paraense, que é não apenas meu lugar de morada como lócus de todas as minhas pesquisas anteriores.

Assim, somado a este formato e primando por um recorte mais detido, escolhi buscar o contexto urbano em cada videoclipe justamente por ir de encontro à imagem idílica que descrevi anteriormente. Apostar na cidade como cenário principal (quase uma personagem) destes vídeos, todos com pouca ou nenhuma alteração/interferência 
física ou gráfica de Belém, reforça um sentido documental, também uma escolha de quem o produziu. Por isto, me voltei para os pontos de vista de produtores audiovisuais (mais especificamente quem ocupou o cargo da direção dos vídeos escolhidos), dos músicos (alguém que falasse pela banda, cantores, grupo) e das pessoas que vivem os espaços que foram filmados, para que saibamos até onde veem e reconhecem a si e seu entorno retratados no vídeo.

Nesta linha, minha busca era por vídeos que fossem de bandas/músicos/grupos locais e diretores que vivem/viviam em Belém na época da filmagem, e que tivessem as ruas da capital paraense como cenário principal. A escolha parte do princípio de que as entrevistas seriam com pessoas que retratam esta cidade a partir de experiências reais, que tenham tido a oportunidade de convívio para conhecer o entorno para além de estrangeirismos, conforme exposto anteriormente.

No decorrer da pesquisa notei que a partir do ano de 2010 a produção audiovisual de/em Belém vem se intensificando, seja por conta de iniciativas independentes ou mesmo investimentos através de editais públicos que, ainda que escassos, possibilitam experimentações. Acrescento a criação da graduação de Bacharelado em Cinema e Audiovisual na Universidade Federal do Pará (cuja primeira turma iniciou no ano de 2011) como uma das responsáveis pela crescente, visto que a formação de pessoas que pensam e realizam o audiovisual reflete também no mercado. Deste modo, desde o final desta primeira década até o início da seguinte, notei um aumento no número de videoclipes belemenses. Por prezar pelo aprofundamento nas pesquisas, mantendo contato com diferentes grupos (músicos, diretores e passantes) de cada videoclipe, delimitei a lista de vídeos a serem pesquisados a partir de alguns pontos como: não incluir videoclipes de canções regravadas ou versões/paródias de músicas já conhecidas (como no caso de Leona Vingativa ${ }^{4}$ ), escolher representantes de categorias e espaços diferentes (videoclipes que se passam em pontos turísticos e periferia, por exemplo), bem como vídeos que tiveram divulgação também fora do estado do Pará, figurando

\footnotetext{
${ }^{4}$ Webcelebridade local, tem feito videoclipes nos últimos anos que podem ser destacados por alguns fatores: por tratar-se de uma figura conhecida através da web, sua produção é local e feita, em sua maior parte, de modo independente, sem apoios ou patrocínios. Seus cenários em geral são ruas consideradas periféricas da cidade, as ruas do bairro do Jurunas são sua principal locação. Seus videoclipes são paródias que falam do universo LGBT com humor, como "Eu quero um boy" (2014), "Frescáh No Círio" (2015), “Não Pode Esquecer o Guanto" (2017) e "Lixo na Sua Cara!" (2018) atingiram grande público, viralizando pelo Brasil e somando fãs à Leona. No entanto, conforme foi comentado, trabalhar com uma análise que envolve videoclipes envereda pela observação da canção e também da imagem, fazendo com que a paródia faça parte de um outro tipo de investigação.
} 
como formador de percepções de terceiros, de um "outro" distante dessa Belém. Seguindo estes critérios, os videoclipes escolhidos foram:

1) "Devorados"

Filmado por entre palafitas da Comunidade da Vila da Barca, o videoclipe ${ }^{5}$ da banda de heavy metal Madame Saatan foi filmado em 2007, dirigido por Priscilla Brasil. A sobriedade das cores e a dinâmica conferida pelas batidas da canção juntamente com as atividades registradas dão ritmo ao videoclipe.

Figura 1 - Quadros do videoclipe "Devorados"

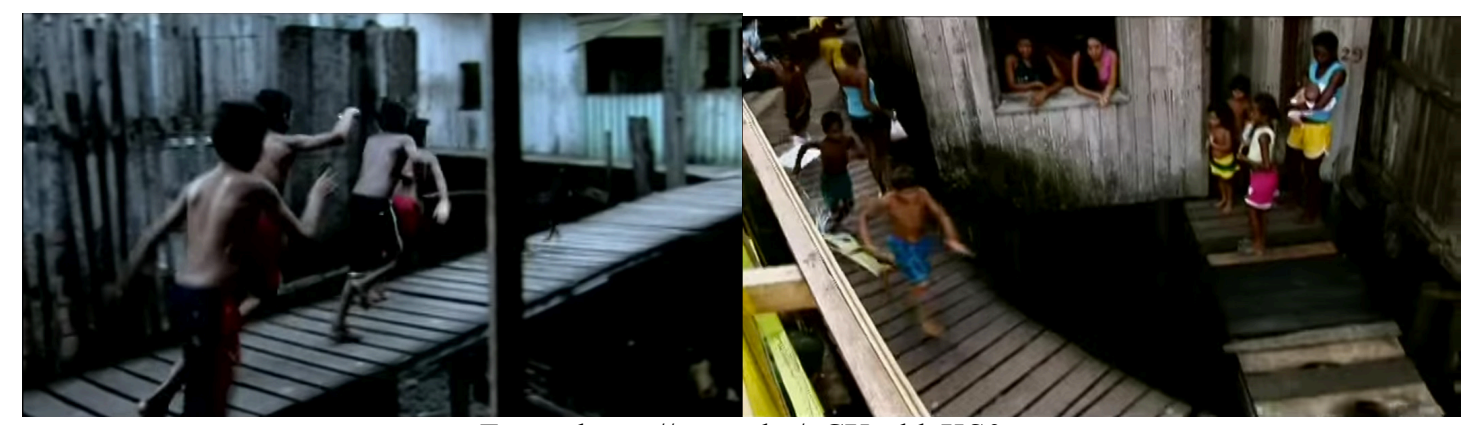

Fonte: https://youtu.be/oCXzsldeKS0

A noite acordam e são devorados

Eles os mesmo, as ruas, as horas

Sentem o que acham que existe

Por que temem e não descobrem

Desespero, ordem das almas insones

Fingem e costumam estar

Dormindo nos braços da estátua

Com folhas nos dentes

Cenas do cotidiano do local são mostradas: pessoas nas portas de suas casas, mulheres fazendo as unhas, crianças brincam de empinar pipa, correm por entre as tábuas de madeira, suas "ruas", jogam-se no rio. A presença da polícia e o trecho cantado "Desespero, ordem das almas insones", são exemplo dessa realidade que foi cantada pela banda, em que seus personagens convivem todos os dias. Considerado um dos lugares mais perigosos de Belém, a Vila da Barca vem passando por um processo de reurbanização que já dura mais de dez anos, que tem por objetivo construir casas de alvenaria para as famílias que moram em palafitas, sobre as águas da Baía do Guajará.

\footnotetext{
${ }^{5}$ Videoclipe "Devorados", da banda Madame Saatan. Disponível em < https://youtu.be/oCXzsldeKS0 $>$ Acesso em 28 mai. de 2017.
} 
2) "Vela"

Segundo videoclipe da banda Madame Saatan selecionado, o "Vela" também foi dirigido por Priscilla Brasil, no ano de 2009. Desta vez, durante a Trasladação, procissão que faz parte da programação do Círio de Nossa Senhora de Nazaré ${ }^{7}$, maior festejo católico do Brasil. A caminhada de fiéis acontece durante a noite do sábado que antecede a procissão principal teve a vela como protagonista deste vídeo, símbolo do sagrado e do profano, simultaneamente, presente em cenas dinâmicas e sempre com muitas pessoas.

Figura 2 - Quadros do videoclipe "Vela"

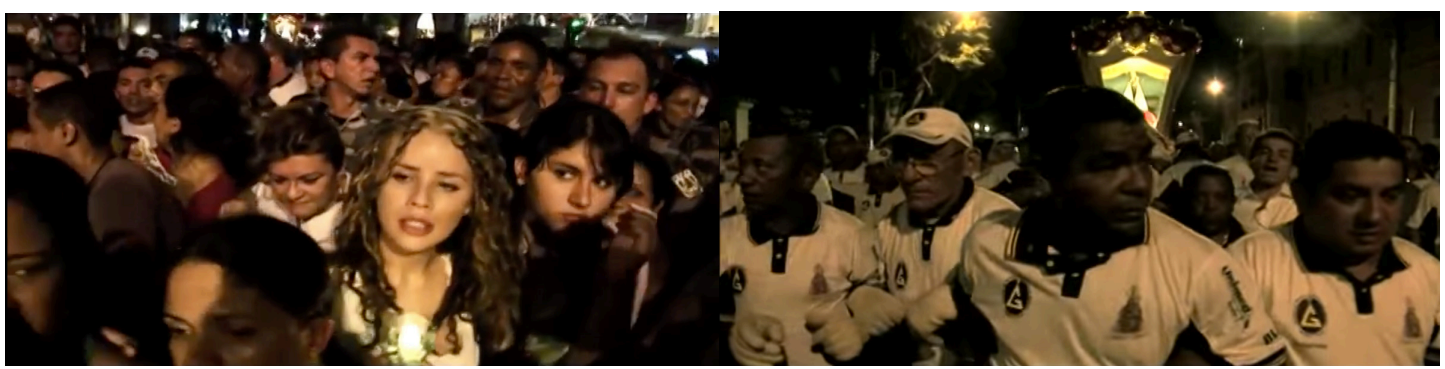

Fonte: https://www.youtube.com/watch?v=MjF9zax5d40

Na hora divina da vida mundana

Fogos nas fitas em braços

Que acendem velas pra Deus, Diabo

Rezam e dançam o Auto do Céu

Profano circo, sagrada força

Ninguém dorme

Antes bebe com entidades e santos

Só dança quando passa a última vela chorando

Lançar na rua os fogos

Dormir noite de mantos

Chorar, enquanto gente

Que passa, reza e chove

Enfim soltar cordões de pássaros

Deixar que ateu até seja

Ninguém está condenado

\footnotetext{
6 Videoclipe "Vela", da banda Madame Saatan. Disponível em $<$ https://www.youtube.com/watch?v=MjF9zax5d40>Acessado em 09 jul. 2017

7 A maior procissão religiosa realizada no Brasil, o Círio de Nossa Senhora de Nazaré acontece no segundo domingo de outubro, em Belém do Pará, desde 1793. Com público estimado de 2 milhões de pessoas que caminham pelas ruas da capital paraense em homenagem à padroeira. Por sua grandiosidade e simbolismo, o Círio foi registrado, em setembro de 2004, pelo Instituto do Patrimônio Histórico e Artístico Nacional (IPHAN), como Patrimônio Cultural de Natureza Imaterial. O dossiê completo sobre o Círio de Nazaré está disponível em $<$ http://portal.iphan.gov.br/uploads/publicacao/PatImDos_Cirio_m.pdf $>$. Acesso em 12 de set. 2017.
} 
Ninguém está aprovado

No meio da procissão, como uma das promesseiras, a cantora Sammliz, vocalista da banda, carrega uma vela por entre o sufoco de estar entre a multidão que roga à Santa. Ao mesmo tempo, as luzes da Berlinda que leva Nossa Senhora de Nazaré são um ponto luminoso indicativo da fé, em contraponto com o fogo e as velas da Festa da Chiquita, programação que já tradicionalmente faz parte dos festejos da época, mas que possui teor "profano", sendo um show logo após a procissão que é feita para o público LGBT desde a década de 1970. Há divino e mundano junto, Deus e Diabo na mesma procissão.

\section{3) "Live In Jurunas"}

A cantora de tecnobrega Gaby Amarantos, dirigida por Priscilla Brasil e Vincent Moon, filmou o show aberto "Live In Jurunas" ${ }^{8} \mathrm{em}$ um palco em frente à casa em que a cantora morava, no referido bairro belenense, considerado periférico e um dos mais populosos da cidade.

Figura 3 - Quadros do show "Live In Jurunas"

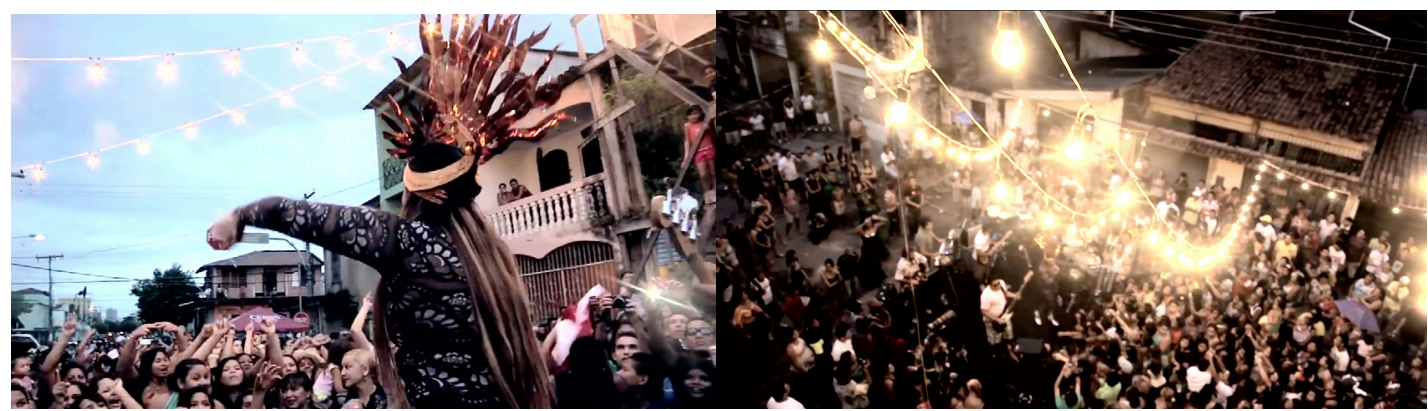

Fonte: https://www.youtube.com/playlist?list=PLmVgB5jJHUPAgTFruEJ4S0Sn1Ajfw20ta

E é assim que a gente vai

Nesse som que é demais

Reuni minha galera

Pra gente enlouquecer.

Galera da laje curtindo com você, meu bem

Vem pra nossa festa que hoje eu quero só você

Laje, laje, a galera da laje

(...)

8 Playlist com as faixas de "Live in Jurunas", de Gaby Amarantos. Disponível em: $<$ https://www.youtube.com/playlist?list=PLmVgB5jJHUPAgTFruEJ4S0Sn1Ajfw20ta> Acesso em 13 fev. 2018 . 
Laje, laje, é festa de aparelhagem

O apelo popular que a cantora carregava no início da carreira bem como a associação à sua origem periférica conferem um resultado com cunho documental, intercalado com as músicas, existem cenas do cotidiano das proximidades. Filmado em 2011, são mostradas cenas do show sendo anunciado por carros-som, pessoas andando nas ruas, outras dançando, carrinho de bebê, entre outras atividades corriqueiras. No site de compartilhamento de vídeos YouTube, no canal da cantora, existe a versão completa, com o show na íntegra, e também a versão de cada faixa cantada no show como um videoclipe isolado, resultando em sete vídeos musicais, o que possibilita duas formas diferentes de consumo e compartilhamento e, por isso, incluso nesta pesquisa. A letra de música acima é "Galera da Laje".

\section{4) "Velocidade do Eletro"}

Filmado no centro comercial de Belém, o vídeo da Gang do Eletro foi dirigido por Brunno Regis e Carol Matos, no ano de 2013. Os integrantes da banda de tecnomelody Waldo Squash, Maderito, Keila Gentil e William Love andam por entre barracas, vendedores ambulantes e lojas, cantando e dançando, fazendo movimentos do ritmo, em "Velocidade do Eletro".

Figura 4 - Quadros do videoclipe "Velocidade do Eletro"

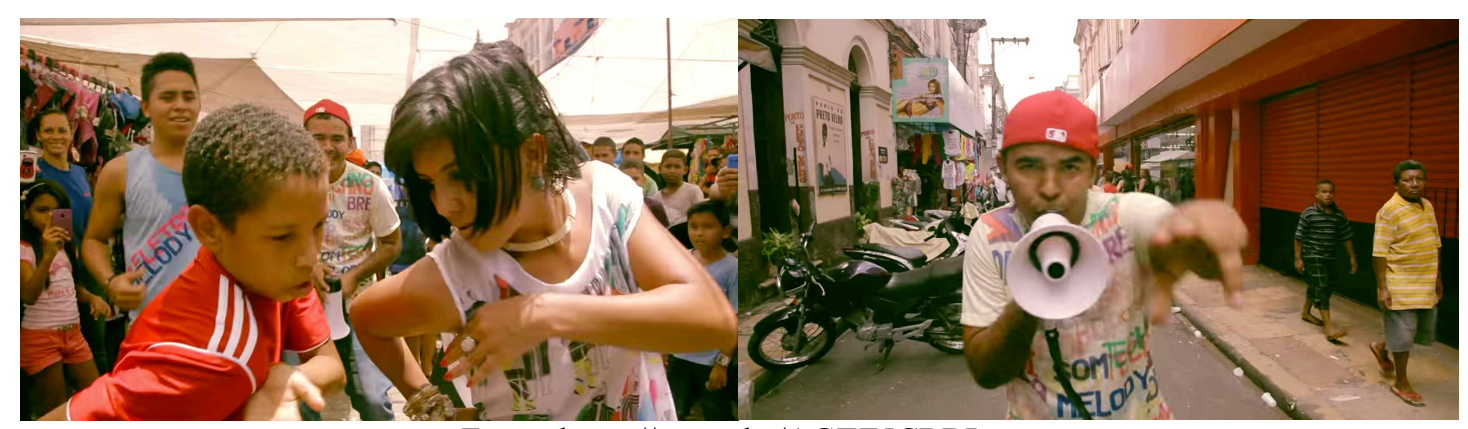

Fonte: https://youtu.be/AGTZ5CBBLso

Vamos lá, vamos lá ver a galera delirar

É na batida do eletro, é nessa onda que eu vou

Chegou velocidade pra galera do setor

Essa onda desguiada

Sacode a cidade

9 Videoclipe "Velocidade do Eletro", do grupo Gang do Eletro. Disponível em < https://youtu.be/AGTZ5CBBLso> Acesso em 20 mai. 2017. 


\section{Te prepara meu amor que vai rolar velocidade}

$\mathrm{Na}$ imagem, o caos visual com o sol de Belém, as placas das lojas e seus produtos, prédios antigos, os rostos curiosos assistindo a um fenômeno pouco comum nesta área, que é a filmagem, nas estreitas ruas e em horário de grande movimentação. O ritmo da música se mistura à intensa dinâmica do local. Na letra, expressões que aproximam o público do ritmo cantado, como em "Chegou velocidade pra galera do setor" e o ritmo que incita seus ouvintes à dança. Interações estas, aliás, que demonstram como o tecnobrega faz parte deste espaço. Além de conhecido, ouvido e dançado por quem transita pelo comércio, também é divulgado pelos vendedores ambulantes e pequenas barracas, que usam o som para ambientar suas lojas ou como produto, vendendo os CDs de grupos locais do ritmo.

\section{5) Oswald Canibal}

O bairro da Cidade Velha é o cenário de "Oswald Canibal" "10, filmado no ano de 2014, em que Henry Burnett, músico e professor universitário, canta uma Belém cujas transformações em relação a um passado idílico já não condizem com o que se nota na contemporaneidade.

\section{Até você, Canibal, daria risada \\ E passaria aperto nessa selva magricela \\ Por aqui o pessoal ainda abre a janela \\ E não vê que é o mesmo que abrir um jornal}

Figura 5 - Quadros do videoclipe "Oswald Canibal"

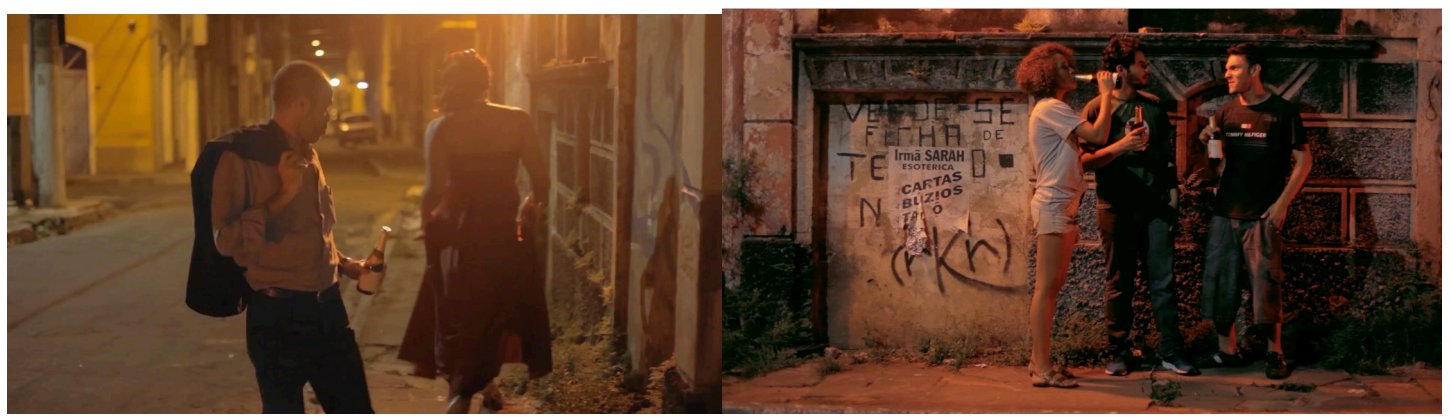

Fonte: $\underline{\text { https://youtu.be/zMfiV0RnY68 }}$

O videoclipe dirigido por Rodolfo Pereira mostra alguns destes personagens

10 Videoclipe "Oswald Canibal", do músico Henry Burnett. Disponível em <https://youtu.be/zMfiV0RnY68 > Acesso em 14 jan. 2016. 
comuns pelas redondezas deste bairro: jovens consumindo bebidas e drogas, garotas de programa, um bêbado. Seus sujeitos em situações decadentes fogem da paisagem de uma Belém turística, da imagem natural, apresentando mazelas típicas da urbanicidade de muitas das metrópoles brasileiras, de uma forma saudosista mas que não se deixa enganar pelas imagens pretéritas.

A arquitetura de algumas casas ainda mantém algumas características coloniais, outras partes, são muros pichados, lixo pelo chão, retratos de uma cidade abandonada. A luz amarela é um traço característico do videoclipe, remetendo diretamente aos postes das ruas da cidade, principalmente nesta área histórica.

\section{6) "No Meio do Pitiú"}

Em seu primeiro videoclipe ${ }^{11}$, Dona Onete canta carimbó em um dos mais conhecidos e registrados complexos turísticos de Belém: O Mercado do Ver-o-Peso, maior feira ao ar livre da América Latina, vende gêneros alimentícios, temperos e ervas medicinais tradicionais. Acompanhada por dançarinos de carimbó, balança sua saia enquanto relata a ida e volta de um urubu ao seu lugar de origem, no Ver-o-Peso, no meio do "pitiú", que é uma expressão usada para caracterizar o cheiro predominante por toda a área onde ocorre a chegada, tratamento e venda de peixes.

Figura 6 - Quadros do videoclipe "No Meio do Pitiú"

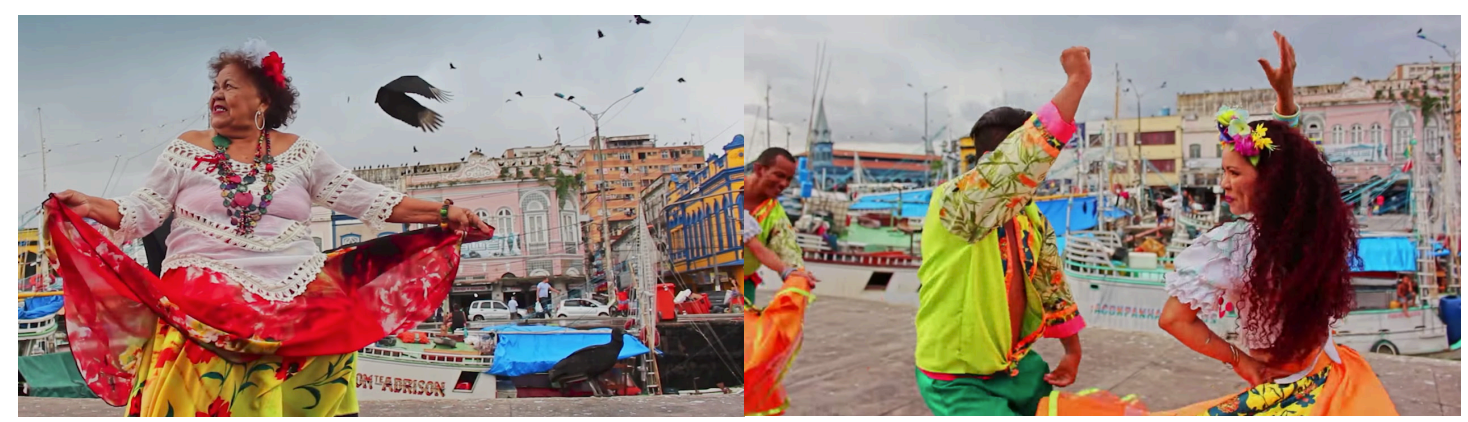

Fonte: https://youtu.be/CkFpmCP-R04

A garça namoradeira

Namora o malandro urubu

Eles passam a tarde inteira

Causando o maior rebu

Na doca do Ver-o-Peso

No meio do Pitiú

No meio do Pitiú, no meio do Pitiú (...)

\footnotetext{
${ }^{11}$ Videoclipe "No Meio do Pitiú", da cantora Dona Onete. Disponível em $<\underline{\text { https://youtu.be/CkFpmCP- }}$ R04> Acesso em 15 dez. 2017.
} 


\section{Eu fui cantar carimbó}

Lá no Ver-o-Peso

Urubu sobrevoando

Eu logo pude prever

Parece que vai chover

Parece que vai chover

Depois que a chuva passar

Vou cantar carimbó pra você

As cores das vestimentas tanto da cantora, quanto dos dançarinos de carimbó são bastante chamativas, remetendo à dinâmica do ritmo. Os urubus e a localidade, que permitem entrever os barcos ancorados, bem como seus vendedores, que tratam e vendem peixes dizem muito sobre algumas características comuns ao cotidiano paraense, assim como o costume de saber da chuva comum a partir do voo dos urubus. O ritmo do carimbó, em geral, entrega isto: arranjos dançantes e letras que falem da própria dança ou situações costumeiras.

\section{O audiovisual e a cidade-cenário}

O surgimento do cinema tem uma raíz documental, de observação e captação do cotidiano, que também foi utilizada pela antropologia, em suas primeiras aproximações, quando ambos os campos estavam em seu início, inclusive. Temos os registros de Margaret Mead e Gregory Bateson, David e Judith MacDougall e, os de Jean Rouch, como os mais estudados quando se trata do início da produção de conhecimento antropológico através de narrativas fílmicas.

Registrar locais e pessoas passou pelo filme etnográfico, pelo jornalismo, então ganhou outros formatos, o audiovisual vem se diversificando intensamente ao longo dos tempos. Como uma forma de fazer a observação da cidade de Belém do modo que me propus, escolhi trabalhar com videoclipes, por trazerem o som como um elemento que soma à observação que poderia ser "apenas" de cunho visual. Assim, lancei mão da antropologia do cinema (Piault, 2018) ou audiovisual, como também é conhecida, para que o âmbito do ver-ouvir integrasse mais dados observáveis à pesquisa.

Especificando o recorte, escolhi trabalhar com o videoclipe, um formato que difere dos clássicos falados (curta/longa-metragem, documental, jornalístico, etc) por suas logísticas e tempo de produção, assim como dispõe de maior liberdade de linguagem e estética que permite explorar nuances que podem ir desde o documental até 
a videoarte, passando pelo ficcional, sendo a experimentação livre em diversos sentidos. Com esta autonomia, os criadores têm em suas mãos possibilidades ainda mais diversas de representação que podem ser inscritas no roteiro e nas demais fases da produção, o campo de criação se multiplica. Então, se há maior licença para imaginar e desenvolver ideias, entendo que as referências de cada um dos que atuam na concepção de ideias também são mais livres neste sentido.

Soares (2006) ressalta que música e imagem devem ser igualmente observados quando se trata de um videoclipe em que, de modo geral, ambos importam da mesma forma, sua ambivalência deve ser respeitada e considerada também no momento de analisar materiais do tipo. Assim, considerando letras, melodias, ritmos mas também cores, enquadramentos, objetos de cena, movimentos de câmera e etc. Sobre videoclipes, o autor diz que:

Freqüentemente refletem a estrutura da canção e se apropriam de certos artefatos musicais no domínio da melodia, ritmo e timbre. A imagem pode até parecer imitar as batidas e fruições do som, indeterminando, com isso, as fronteiras entre som e imagem. Video-makers têm desenvolvido uma série de práticas para colocar a imagem na música na qual a imagem adquire um status de autonomia e abandona certos modos de representação mais direta da canção. Em troca, a imagem ganha em exibilidade e desenvoltura, assim como na polivalência de significados. Muitos dos signficados do videoclipe recaem neste dar-e-pegar entre som e imagem e nas relações entre seus vários modos de continuidade. (Mundy apud Janotti Júnior; Soares, 2008: 94)

Som e imagem têm uma relação direta no vídeo musical assim como também podem ter sua autonomia, conforme o autor. São dois materiais independentes que, juntos acrescentam e recriam um ao outro. A estética, a montagem, as formas de criar videoclipes estão em constante renovação. A montagem e o ritmo são as peças-chave para este tipo de vídeo ${ }^{12}$. Um dos principais motivos da criação de videoclipes foi a divulgação da música e da imagem de artistas, passando por fases em que era o registro de apresentações, promocional (vendendo algum novo trabalho) ou mesmo um outro modo de afirmar a identidade dos artistas em questão, transpassando a canção e chegando à estética visual. $\mathrm{O}$ diferencial do videoclipe deve ser respeitado e atentamente observado desde a produção até sua divulgação, segundo Bryan (2009) ${ }^{13}$, é “o gênero que melhor se adapta aos diferentes espaços de divulgação, seja na televisão,

\footnotetext{
${ }^{12}$ Mais sobre a história, o desenvolvimento e a estética dos videoclipes em "Videoclipe: o elogio da desarmonia", de Thiago Soares, 2012.

13 Entrevista de Guilherme Bryan disponível em: <www.revistapontocom.org.br/edicoes-anterioresentrevistas/a-linguagem-do-videoclipe $>$ Acesso em 25 jun. 2016.
} 
no cinema, no telefone celular e na internet, por ser relativamente curto e encantar em poucos segundos", o que afeta diretamente seu ciclo, visto que pode ser produzido mais rápido e, principalmente, alcançar um público expressivo pelos diferentes canais de divulgação possíveis.

O processo de consumo implica também em dados como a popularidade do músico/banda, formas de difusão, assim como o ritmo em questão. Já o processo de criação é muito mais variável, indo desde formação de equipe, locações e roteiros até questões financeiras, que implicam diretamente no modo como o projeto será colocado em prática. Existem curtas-metragens, longas, séries e videoclipes sendo filmados no estado do Pará com maior frequência nos últimos anos ${ }^{14}$, no entanto, como ainda não se trata de um cenário audiovisual fortalecido e estruturado (seja por falta de profissionalização de equipe, seja por falta de incentivo financeiro para tal), a maior parte das produções têm sido de cunho experimental e/ou independente, fazendo com que o videoclipe seja um dos formatos mais frequentes e exequíveis neste contexto belenense.

Estudar e observar estes materiais passa pelo histórico da cidade e suas formações, que é paralelo ao da análise dos fenômenos observados, atentando para os acontecimentos e caminhos percorridos, que resultaram nas percepções cotidianas criadas por e em cada um dos habitantes. Assim como Oliveira, ao meu ver, a análise de quaisquer tipos de arte, não pode ser tratada

(...) como reflexos de uma realidade, nem como moldura que encerra um conteúdo, e sim como evocações do real, que com ele mantêm uma relação, mas que a ele não se submetem e não se curvam, e sim lhe dirigem um olhar e querem ser retribuídas (...). A arte, os objetos estéticos, excedem a experiência no sentido restrito, porque se ligam aos vários âmbitos da cultura e, deve-se complementar, estão ligados à linguagem estética que pode prescindir de uma referencialidade direta. (Oliveira, 2011: 17-20)

Ao dialogar com os interlocutores, não busco encerrar o assunto ou as percepções dadas, mas compreender que se trata de um olhar, ciente de que a arte se trata também

\footnotetext{
${ }^{14}$ No ano de 2016 houve significativa produção audiovisual no estado, incluindo a gravação de uma série para televisão, dirigida por Roger Elarrat, chamada "Squat na Amazônia", assim como filmagens de a série "Sabores da Floresta" e o filme "O Reflexo do Lago", pelo diretor Fernando Segtowick. Em 2018 o importante lançamento de "Para ter onde ir", de Jorane Castro, marco na retomada da produção de longas-metragens no estado. $\mathrm{O}$ cenário independente tentou outros meios e, um deste exemplos, o projeto universitário "A Besta Pop" também foi filmado neste ano, após conseguir colaborações através de financiamento coletivo, com equipe formada por estudantes de cinema e audiovisual, teatro e música da UFPA.
} 
de escolhas e referências. É através da cotidianidade, das atividades corriqueiras, dos personagens familiares, casas e outros tipos de imóveis que emergem significações. São variados aspectos de uma mesma cidade, que coexistem e que por vezes reafirmam o olhar colonial, outras, combatem. Marcando, então, o papel social do audiovisual (e mesmo da arte como um todo) enquanto ferramenta que ajuda a construir o imaginário, bem como ser político e gerador de conhecimento histórico-social sem perder seu aspecto de entretenimento. Ao mesmo tempo, a memória também é base destas experiências e percepções contemporâneas frente às diferentes apropriações da cidade. O tanto que nós, enquanto belenenses e/ou amazônidas conhecemos o nosso histórico e o espaço em que vivemos é nítido quando se tornam tema de nossas expressividades, conhecemos aquilo que ouvimos falar, o que lemos, o que aprendemos na escola.

No campo do audiovisual, em que a escolha do local em que será feita a filmagem é resultado de diálogos entre a direção geral, a direção de arte e a direção de fotografia, que pensam a organização do que estará dentro do quadro. O espaço é construído de algum modo, seja para acomodar uma série de objetos, novas disposições de paredes ou auxiliar no desenvolvimento de uma cena, comportando atores e suas ações.

Aqui, então, inicia-se a mescla do vídeo com a urbe. A paisagem, como elemento que altera e é alterada pelos seus passantes, pelos acontecimentos históricos e pelo tempo é percebida de diferentes formas por cada pessoa, dependendo diretamente de sua experiência e interações com o local, fatores sociais também influenciam diretamente. Conforme Silveira:

Qualquer ideia e/ou percepção de paisagem está imersa em um processo cognitivo vinculado ao jogo sutil de adesão às imagens que a mesma suscita e, assim, a uma perspectiva estética, uma vez que toda paisagem implica a presença de uma dimensão sensível e emocional por parte do humano (Silveira, 2009: 72).

Ao andar por trechos da cidade em que foram filmados os videoclipes, por exemplo, são reconhecíveis as paisagens-cenário, principalmente as mais frequentes. Dentre os interlocutores desta pesquisa, pessoas que convivem nestes espaços cotidianamente - seja em condição de moradia, seja passagem ou trabalho - há um consenso de que o interessante para quem não vive em Belém, o que é preferencialmente filmado, é o Mercado do Ver-o-Peso, cartão postal da cidade.

Por volta das $8 \mathrm{~h}$ da manhã, ao andar na Boulevard Castilhos França, rua cujo lado direito tem o Complexo do Ver-o-Peso e, do esquerdo, as diversas ruas do centro comercial, logo nota-se a diferença de movimentação. Enquanto no Mercado a agitação 
começa de madrugada, com venda de peixes, frutas, legumes e mesmo as ervas, as barracas e lojas de vendas, do outro lado da rua as vendas e compras demoram um pouco mais a acordar. O fluxo de pessoas, cores, cheiros e sons diversos (geralmente vários estilos de brega) do Ver-o-Peso é o que, em geral, recebe quem chega lá, seja de carro ou de ônibus. Sentir o "pitiú" 15 cantado por Dona Onete, ali, é inevitável.

Ao adentrar as ruas mais estreitas do lado esquerdo, barracas ainda sem vendedores ou produtos, apenas com o suporte de madeira e a coberta plástica azul. As lojas, que têm horário marcado, logo abrem, acompanhadas dos carrinhos de lanches e café da manhã, que atendem trabalhadores e clientes do comércio. Aos poucos cada banca vai se abrindo, arrumando, com diversos sons (seja da rádio do comércio, das lojas ou de alguma "bike-som" que passa pelas proximidades) e já é possível começar a ver o comércio que é retratado pela Gang do Eletro. Movimentado, colorido, com gente andando para todos os lados. Por volta das $9 \mathrm{~h}$ da manhã a movimentação já está misturada, assim como os públicos por toda esta área.

Para a erveira Beth Cheirosinha, conhecida por dar entrevistas, participar de vários registros audiovisuais, inclusive do próprio videoclipe da Dona Onete, "No Meio do Pitiú", falar do que a cidade oferece, ou do próprio Ver-o-Peso, é uma forma de atrair público e clientes, mas disse que quem vai visitar o ponto turístico se depara com uma realidade diferente do que os próprios jornais locais mostram: lixo, pontos descuidados, falta de manutenção. As mesmas reclamações foram feitas por dona Marilda, que tem um carrinho de lanches no centro comercial, que disse que gosta que "mostrem a verdade", o que acontece no cotidiano do comércio, os vendedores e lojas, mas que isso infelizmente inclui retratar a cidade maltratada. Ambas atribuíram a situação das ruas da cidade à prefeitura. No fim das contas, disseram que filmagens nesta área servem como divulgação dos seus trabalhos, figurando como benefício, ainda que esteja sujeito aos entraves citados.

Figura 7 - Peixeiros e garça em "No Meio do Pitiú"

\footnotetext{
${ }^{15}$ Cheiro forte característico de quando se passa pelo Complexo do Ver-O-Peso, pelo manuseio de peixe.
} 


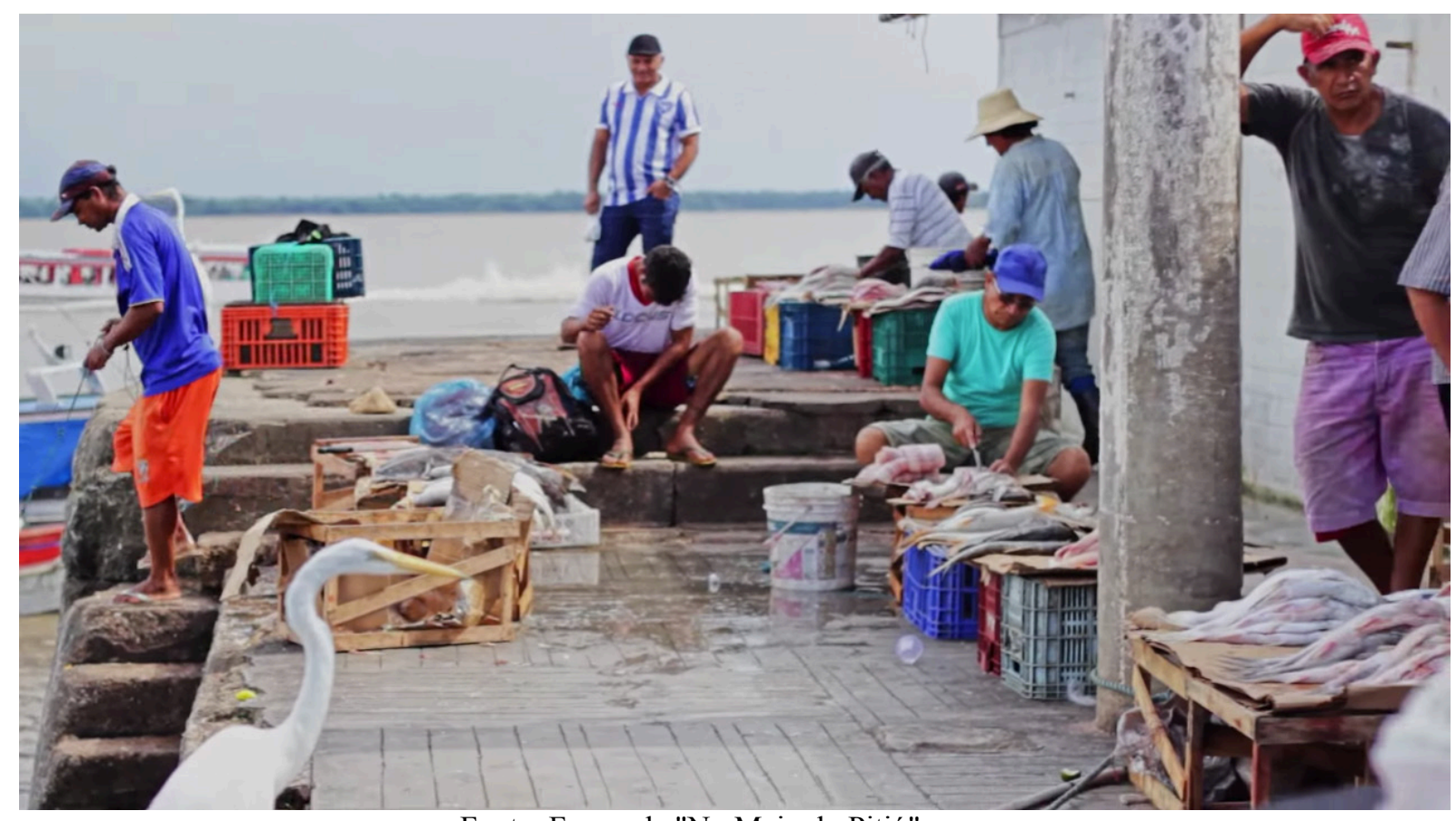

Fonte: Frame de "No Meio do Pitiú"

Sobre a frequência do Ver-o-Peso em filmagens, também foi uma confirmação feita por Neide, vendedora de comidas típicas em uma barraquinha na Avenida Nazaré que, às vésperas do Círio, estava com intenso ir e vir de pedestres, entre estrangeiros e crianças saindo da escola, embaladas pelo sino da Basílica de Nossa Senhora de Nazaré, que marcava às $18 \mathrm{~h}$, horário da missa. A vendedora também disse que, em geral, os turistas se interessam pela gastronomia local. Ela, enquanto parte deste ramo, também já foi entrevistada outras vezes e acompanhou pessoas que filmaram vídeos e matérias sobre os sabores de Belém, que dificilmente escapam de visitas ao Mercado do Ver-oPeso.

Já para Madeirito, integrante da Gang do Eletro, e Carol Matos, diretora do videoclipe "Velocidade do Eletro", o que se pretendia mostrar era a interação entre pessoas, a movimentação que é típica do centro comercial, mesclado às lojas, barracas e sol forte que constroem a paisagem deste local. Na época, a criação de uma imagem audiovisual que fosse associada ao grupo de tecnomelody era essencial, no entanto, havia falta de verba para o mesmo. Assim, de forma criativa, a filmagem neste espaço supriu não apenas a questão financeira da produção, como também agregou a característica do grupo de estar dentro de um dos grandes centros de divulgação da sua música, visto que a distribuição desse estilo é vastamente conhecida por operar através da pirataria. Hoje indo além da gravação de CDs piratas e chegando a pen drives personalizados gravados ali mesmo, como na barraca cheia de LEDs e equipamentos no 
meio do comércio, onde o DJ André do Comércio (apresentado a mim por Maderito, que é seu amigo), por exemplo, monta playlists, salva em um dispositivo e entrega aos seus compradores.

Figura 8 - DJ André do Comércio e a disseminação do tecnobrega

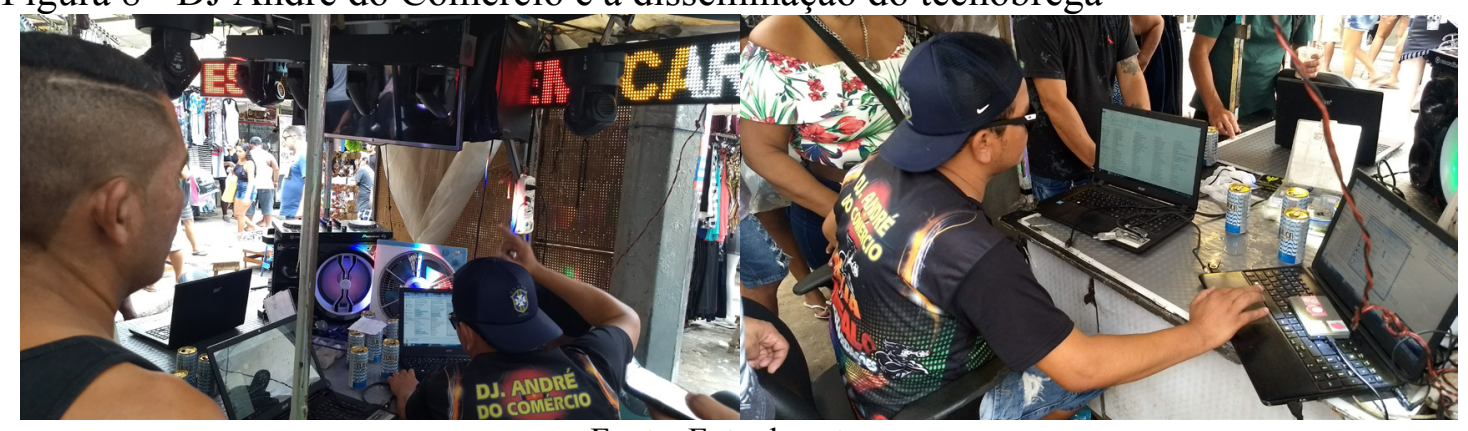

Fonte: Foto da autora

Através destas observações é possível vislumbrar não somente as atividades que ocorrem no cotidiano, mas o que o espaço em questão contém enquanto traços de historicidade. Ao considerarmos simbolismos nos locais para uma análise através de um produto audiovisual, deparamo-nos com duas vias de observação: os aspectos inerentes ao contexto urbano cotidiano e os símbolos transpostos para o vídeo, como escolhas de imagetizações e percepções de um espaço, que não necessariamente serão os mesmos. Através de intersubjetividades como as que ocorrem no comércio, supracitadas, é possível entender o espaço citadino que foi transposto para o videoclipe, seja através dos símbolos do tecnobrega na banca do DJ (luzes, computadores, pen drives, blusa personalizada, telas), seja nas pessoas que frequentam o espaço ou na agitação cotidiana, que envolve placas, lojas e dinâmicas de vendas.

Leonardo Augusto, diretor do videoclipe "No Meio do Pitiú", que tem a paisagem mais turística dentro do recorte observado, acredita que quando se filma "de dentro" (Magnani, 2002), é possível transpassar sua familiaridade para o vídeo. Ao chegar para a entrevista (realizada na Estação das Docas), disse que passou pelo Ver-o-Peso, como costumeiramente passa e acredita que o trajeto faz parte do cotidiano de muitos belenenses também. Ele diz que os casais de dançarinos de carimbó na Pedra do Peixe (área de descarga de peixes dos barcos que vêm de ilhas e localidades próximas, que faz parte do Complexo do Ver-o-Peso) fazem parte de um "realismo fantástico", por não serem figuras cotidianas naquela área. Ainda atesta que, assim como as tomadas feitas de urubus, que são bichos rejeitados no dia-a-dia, por exemplo, foram importantes para afirmar a presença deles ali e retratar uma certa aceitação de que fazem parte daquele 
contexto que foi retratado, apesar do exagero da forma representada para acessar o pertencimento à cultura local.

Para Priscilla Brasil, diretora de três dos vídeos escolhidos, todos surgiram do que, para ela, emanava das canções. E, em dois deles (os filmados no Jurunas e na Vila da Barca) a periferia emerge não somente como local possível quando não se tem verba, mas sua força plástica e sua cotidianidade conferem também uma carga histórica para os vídeos. A diretora se mostrou ciente de que muitas pessoas além de não viverem (n)estes espaços, desconhecem completamente o que se passa dentro de um bairro da periferia, em ruas que não são acessadas nos caminhos comuns, o que faz com que os habitantes de Belém ainda tenham que se aprofundar mais nas próprias vizinhanças para poder produzir mais, falar de temáticas recorrentes que, por vezes, estão inseridas em outras camadas da própria cotidianidade. Conhecer previamente os espaços a serem filmados faz parte da produção audiovisual, o que reflete nos registros, como foi feito na filmagem de "Vela", que durou mais de 24 horas, juntando as procissões da Trasladação e do Círio. Priscilla é documentarista e essa característica é visível na filmagem de seus videoclipes, buscando transpassar as experiências adquiridas para as telas. Isto converge na fala de Eckert e Rocha que diz que:

a vida citadina é, portanto, agitada, vertiginosa mesmo, ou monótona e repetitiva, dependendo da adesão ou não dos seus habitantes aos tempos e espaços vividos, ritmados pelos movimentos incessantes das imagens de cidade que habitam seus pensamentos em constante mutação. Descrever a cidade, sob um tal ponto de vista, é conhecê-la como locus de interações sociais e trajetórias singulares de grupos e/ou indivíduos cujas rotinas estão referidas a uma tradição cultural que as transcende (Eckert; Rocha, 2003: 02).

Portanto, conviver e registrar a vida citadina é saber que ela é formada por vários grupos, várias atividades, históricos conhecidos ou não que vão emergir e vão se fazer presentes de alguma forma. Logo, é imperativo saber lidar com estas características da vida na cidade. Seja o que acontece todos os dias, seja o que acontece sazonalmente, como no caso da manifestação religiosa.

\section{Representações e experiências}

Diante das entrevistas que realizei ao longo da pesquisa, como visto anteriormente, a demanda de mostrar uma "realidade" quando se fala de Belém é, de certo modo, recorrente. A partir destes breves exemplos é possível discutirmos essa passagem do "nós" para a tela, ou o que acredita-se que é esse sujeito e os locais onde 
(con)vive, que são resultantes de experiências cotidianas, que podem vir a gerar conceitos como o de "representação social", de Denise Jodelet:

Les instances et relais institutionnels, les réseaux de communication médiatiques ou informels interviennent dans leur élaboration, ouvrant la voie à des processus d'influence, voire de manipulation sociale - et nous verrons qu'il s'agit là de facteurs déterminants dans la construction représentative. Ces représentations forment système et donnent lieu à des "théories" spontanées, versions de la réalité qu'incarnent des images ou que condensent des mots, les uns et les autres chargés de significations - et nous verrons qu'il s'agit là des états qu'appréhende 1'etude scientifique des représentations sociales. Enfin, à travers ces diverses significations, les représentations expriment ceux (individus ou groupes) qui les forgent et donnent de l'objet qu'elles représentent une définition spécifique. Ces définitions partagées par les membres d'un même groupe construisent une vision consensuelle de la réalité pour ce groupe. Cette vision, qui peut entrer en conflit avec celle d'autres groupes, est un guide pour les actions et échanges quotidiens - et nous verrons qu'il s'agit là des fonctions et de la dynamique socIales des représentations. (Jodelet, 2003: 52$)^{16}$

Devo dizer que concordo no envolvimento de mídias e redes que contribuem para a influência e disseminação de formas de representação que surgem entre grupos e indivíduos com significados que podem não ser os mesmos dos empregados por grupos outros, e acho que é neste sentido que a colocação do conceito passa a não fazer sentido para ser aplicado nesta pesquisa. Discordo da "representação" de Jodelet quando diz que é uma "imagem sobre o real", falando diretamente à produções feitas por indivíduos daquela sociedade e daquele contexto. Acredito que este sentido de interpretações e significados atribuídos por grupos (logo, possivelmente limitado) e que se espalham através das redes de relacionamento perpetuam ou favorecem também estas "representações", a partir da ótica daquele que desconhece, difundindo sentidos que não contemplem o suposto objeto ou sujeito "representado", é a padronização ou um modelo eleito para quando for necessário se referir a um dado grupo ou característica.

\footnotetext{
16 “Instituições e redes institucionais, mídia ou redes informais de comunicação estão envolvidas em seu desenvolvimento, abrindo caminho para processos de influência, até mesmo de manipulação social - e veremos que esses são fatores determinantes na construção representativa. Essas representações formam um sistema e dão origem a "teorias" espontâneas, versões da realidade incorporadas em imagens ou palavras condensadas, cada uma carregada de significados - e veremos que são estados que o estudo científico das representações sociais apreende. Finalmente, através destes vários significados, as representações expressam aquelas (indivíduos ou grupos) que as forjam e dão ao objeto que elas representam uma definição específica. Essas definições compartilhadas por membros do mesmo grupo constroem uma visão consensual da realidade para esse grupo. Essa visão, que pode entrar em conflito com a de outros grupos, é um guia para as ações e trocas diárias - e veremos que essas são as funções sociais e a dinâmica das representações. (...) É geralmente reconhecido que as representações sociais, como sistemas de interpretação que governam nossa relação com o mundo e os outros, guiam e organizam as condições e comunicações sociais. Da mesma forma, intervêm em processos tão variados quanto a difusão e assimilação do conhecimento, o desenvolvimento individual e coletivo, a definição de identidades pessoais e sociais, a expressão de grupos e as transformações sociais." (Jodelet, 1989: 52-53). Tradução da autora.
} 
Apesar de "representação" e "representatividade" terem sido palavras recorrentes em algumas das entrevistas, no sentido de mostrar a realidade vivida em Belém, acredito que as articulações com a sociologia e a psicologia social agregadas ao termo o afastam do caminho deste texto, que lida com concepção, produção e consumo de imagens fundamentadas na vivência e interações de pessoas com o espaço. O sentido de representação, "substância simbólica” falado por Moscovici (1978), ao meu ver, incita ainda um caminho que leva à uma padronização, mais pautada em uma reprodução que agrega elementos que podem ser externos (no sentido de estrangeiros, olhares superficiais) e/ou "achatadores", niveladores. Deste modo, preferi me dedicar ao conceito de experiência, por lidar com a expressão daquilo que se viu, que se sentiu, a atenção sobre o que foi percebido ao longo dos campos e entrevistas realizados mas, principalmente, sobre as vivências dos interlocutores.

Segundo Bruner, o conceito de experiência "deals with how individuals actually experience their culture, it is, how events are received by consciousness" (1986: 04) ${ }^{17}$, que pode ser revelado não somente de modo verbal, mas através de outras linguagens, outro ponto que me levou a optar pela experiência, considerando o processo de criação do audiovisual. Ainda segundo o autor, não se pode chegar à exata ou completa experiência do outro, mas o que se pode fazer é tentar interpretar suas expressões (Bruner, 1986), o que busquei aplicar no momento de análise e que também acontece ao interpretar expressões ou obras de arte, por exemplo.

$\mathrm{O}$ contato com pessoas que vivem (n)a cidade direciona-se exatamente para as suas experiências nestes espaços, o que faz com que suas narrativas pessoais contribuam diretamente para a formação de narrativas outras, de histórias associadas às imagens de Belém. Por isto, ainda quando eu perguntei sobre os mesmos espaços, cada uma das três ou quatro pessoas puderam dar perspectivas diferentes, a partir daquilo que fez ou faz parte de suas experiências e seus diferentes contextos. Seja pelo seu tempo de contato com o espaço, sua ocupação, sua condição financeira, o tipo de atividade que ela relaciona ao lugar. Ao optar pelo uso deste termo enquanto estratégia teóricometodológica é possível observar as categorias que emergem a partir das interações em campo, não mais partindo de representações estabelecidas historicamente e que invisibilizam tudo aquilo que não se encaixa no perfil dominante, como discorre Scott "Making the movement visible breaks the silence about it, challenges prevailing

17 "lida com o modo como os indivíduos realmente experimentam sua cultura, é como os eventos são recebidos pela consciência. (1986: 04). Tradução da autora. 
notions, and opens new possibilities for everyone" cujo objetivo é "to document the existence of those institutions in all their variety and multiplicity, to write about and thus to render historical what has hither to been hidden from history." (1992: 23).

Assim, retornando para o viés decolonial pretendido nesta pesquisa, de aumentar o escopo para alcançar o máximo de narrativas e percepções que fujam ao que já está posto e se reproduz há tempos. Ressalto que a intenção é pormenorizar os contextos, para que a natureza da experiência se sobressaia, não sendo deslocada de seu sentido e tornando-se "evidência da diferença" (Scott, 1992: 25).

Seguindo a discussão de Scott sobre o termo, é conferida, então, maior relevância ao que é dito pelo interlocutor sobre sua perspectiva e experiência de espaços e contextos. Deste modo, conversar com pessoas que são, ao mesmo tempo, experienciadoras destes lugares e criadoras de "representações" (no sentido de novas significações), paisagens imagéticas, pode vir a conferir ao vídeo musical um tipo de discurso em que se pode registrar variados "viveres" e pode, portanto, gerar novas experiências, compartilhando-as a partir do audiovisual: "Since discourse is by definition shared, experience is collective as well as individual. Experience is a subject's history. Language is the site of history's enactment. Historical explanation cannot, therefore, separate the two." (Scott, 1992: 34) ${ }^{18}$. Assim, agrego também o conceito que Mignolo (2005) busca em Glissant para dar suporte ao seu ponto de vista sobre o imaginário, em que diz que “"o imaginário’ é a construção simbólica mediante a qual uma comunidade (racial, nacional, imperial, sexual, etc.) se define a si mesma" (2005:33). Ele diz que há, no Ocidente, a recorrência de ter uma imagem "exterior interna", criada após longos processos de construção do imaginário, que tem uma exterioridade, mesmo que concebidas por pessoas inseridas no contexto. Acredito ser uma outra forma de entendermos o quanto podemos ser estrangeiros das nossas próprias casas e vizinhanças.

Também utilizando uma lógica próxima a de Jodelet para falar de representação, Joan Scott fala sobre a noção de experiência, que consistiria em construir (ou reconstruir) históricos e contextos a partir de relatos de indivíduos, a partir de suas experiências, e ter estes dados como forma de conhecimento:

\footnotetext{
18 “Já que o discurso é, por definição, compartilhado. a experiência é coletiva assim como individual. Experiência é uma história do sujeito. A linguagem é o local onde a história é encenada. A explicação histórica não pode, portanto, separar as duas.” (Scott, 1992: 34). Tradução da autora.
} 
When experience is taken as the origin of knowledge, the vision of the individual subject (the person who had the experience or the historian who recounts it) becomes the bedrock of evidence upon which explanation is built. Questions about the constructed nature of experience, about how subjects are constituted as different in the first place, about how one's vision is structured-about language (or discourse) and history - are left aside. The evidence of experience then becomes evidence for the fact of difference, rather than a way of exploring how difference is established, how it operates, how and in what ways it constitutes subjects who see and act in the world. (Scott, 1992: 25)

Se tomarmos o conceito de experiência de Scott e retornarmos ao início do texto onde entendemos/definimos a arte como expressão social, ela cumpre também, neste contexto, um papel de reconstrução de si. Explico: Em meio às midiatizações que reforçam a ideia de exotização da região amazônica em detrimento de uma exploração de suas diversidades, emergem estes novos contextos do fazer audiovisual. Em um âmbito mais amplo, temos o movimento Nuevo Cine Lationamericano ${ }^{19}$, que ocorreu nos anos 1960 e 1970 em meio a efervescências ideológicas e políticas em alguns países desta América, retratando a cotidianidade de cidades e suas temáticas a partir do ponto de vista de produtores locais. A produção de videoclipes belenenses e, portanto, sua análise, desvela um novo cenário, talvez um eco desta época ou o início de um outro ciclo, em que vídeos musicais podem ser meios para falar das realidades circundantes a partir de experiências e imaginários próprios. Ao que aqui associamos também ao terceiro espaço, colocado por Bhabha (1996), que é o lugar no qual conceitos não estão resolvidos, podendo, portanto, ser modificados. Ora, se é possível este tipo de modificação a partir de manifestações artísticas/culturais, logo, afirma um dos papeis que o audiovisual pode ter. O caráter fragmentário e ambivalente de qualquer sistema de representação torna, deste modo, o videoclipe passível de quaisquer interpretação a partir do momento em que está entre a divulgação e o consumo, o que potencializa os elementos presentes em cena para indicar caminhos interpretativos a partir do simbólico.

Sobre a formação da imagem da Amazônia, então, enquanto uma área tipicamente de naturezas, discuto aqui uma colocação que pode vir a dar conta das características de algumas cidades da região. Agenor Pacheco, pesquisador da Amazônia e do município de Melgaço, localizado no arquipélago do Marajó, utiliza a expressão "cidade-floresta":

A expressão Cidade-Floresta remete a pensar noções de uma urbanidade singular que se elabora pelos saberes, linguagens e experiências sociais de populações forma-

\footnotetext{
${ }^{19}$ Ler mais sobre o movimento em "Do Terceiro Cinema ao cinema periférico: Estéticas contemporâneas e cultura mundial", de Ângela Prysthon, 2009
} 
das dentro de uma outra lógica de cidade, onde antigos caminhos de roças cedem lugar à construção de ruas de chão batido, depois asfaltadas, assim como a permanência de práticas de viveres ribeirinhos nesses novos espaços de moradia. (Pacheco, 2006: 24).

O autor pensou Melgaço a partir deste contexto, ao considerar a constituição da localidade, seu histórico, características geográficas, econômicas e os grupos étnicos que fizeram parte da sua formação, assim pôde perceber como torna-se uma convergência de acontecimentos tão plurais que não cabem em apenas um lado da dualidade, mas abarca ambos. Ao longo das primeiras entrevistas foi possível notar o quanto está incorporado ao discurso do belenense os aspectos da natureza. No princípio desta pesquisa, em minha própria forma de trabalhar, tinha rua e floresta enquanto uma dicotomia, "ou mostra-se um, ou o outro". O que, de certa forma ocorre na maior parte dos videoclipes aqui observados, enquanto, ao ouvir as pessoas falando sobre características consideradas belenenses ou pontos presentes nas músicas e nas imagens que são reconhecidamente locais, na maior parte das vezes, o lado "floresta" não deixava de emergir.

Ainda que não seja apenas imageticamente, como Pacheco (2013, p. 29) diz, mesmo em Belém, a capital do estado do Pará, uma metrópole, costumes e tradições da "floresta" perduram. Seja nas atividades cotidianas, no alimentar-se de frutos e peixes trazidos das ilhas, nas superstições. Então, passei a assumir Belém como uma "cidadefloresta", afastando-me na superficialidade de tratá-la enquanto um urbano "comum", mas reconhecendo que as características de uma dita ruralidade atuam ainda na cotidianidade, o que confere maior complexidade ao (re)tratá-la.

Para Milton, cuja casa foi a base de produção para o videoclipe "Oswald Canibal", "a arte em Belém acaba sendo impregnada pelo modus vivendi, num bom sentido (...) talvez seja um pouco essa mistura da cidade Belém, da posição geográfica, né, da quantidade de água na baía, as ilhas aqui próximo, que é um outro ambiente”. Já Sammliz, ex-vocalista da Madame Saatan diz que "a gente carregava essa coisa de trazer as sutilezas dessa coisa tão natural pra nós, pelo fato de sermos criados aqui no som, sem 'querer parecer', 'vamos misturar', não era. A gente fazia o que tinha de fazer, o que tava dentro da gente, mesmo". Nota-se, então como o espaço, as atividades, as expressões se convertem naturalmente em elementos artísticos, pois estão presentes nas vivências. Henry Burnett disse que não entende a necessidade de afirmação identitária, de se rotular enquando músico belenense, paraense ou amazônida, visto que 
aqueles que tem como referência criaram suas obras imersos no cotidiano belenense e refletindo o global, apesar de que, também segundo ele:

Mesmo tendo saído da cidade com 27 anos, a cidade, como se diz, nunca saiu de mim. Não apenas porque sempre retorno, mas porque minha formação como compositor se deu aí; os elementos que foram se agregando àquela formação inicial não passam de pequenos aportes ao que considero já estar definido a partir da vivência na cidade; embora importantes, não alteram a rota. Portanto, fazer música em Belém não significa para mim estar na cidade, seria mais correto dizer que, se eu não estiver errado, uma imagem sentimental da cidade segue comigo. "Melancolia" é um bom exemplo (do álbum Não Para Magoar). Compus quando já morava fora, mas quando mostrei a $1^{\text {a }}$ vez ao Charles Matos (baterista) ele disse que era um lundu, e eu não tive nenhuma intenção rítmica quando escrevi, acho que isso mostra a importância da memória do lugar na minha música. (Henry Burnett em entrevista concedida à autora em 03 de outubro de 2018).

Em entrevista com moradores das localidades consideradas periféricas, Vila da Barca e bairro do Jurunas, o pertencimento se fez muito presente. Quando perguntei ao Lucas, que mora a vida toda no bairro, se ele acredita que o "Live In Jurunas" retratou o cotidiano de onde ele vive, respondeu:

Sim, muito. Representa sim, como eu te falei, em todos os sentidos. Tu podes ter uma noção de como é conviver lá e é uma noção bem fiel. Assim, justamente pelo fato d'eu ter te falado da geografia, de como são dispostas as casas lá e tudo mais, mais pra dentro, principalmente, da quantidade de gente, das ruas sempre cheias, das pessoas sempre na rua, sempre conversando, interagindo... que é diferente dos outros bairros mais centralizados. Então mostra essa característica do bairro. Essa característica que eu julgo ser bem humana, assim, sabe? A gente sente muito quando a gente se afasta do nosso bairro, onde a gente cresceu, viveu, convive, por esse fator humano. Como eu tô te falando, é muita gente, todo mundo que mora lá se conhece há muito tempo e convive, sabe da vida do outro, e se mete na vida do outro e vai convivendo, né? Então isso é uma coisa que identifica muito e que passa no clipe. Creio que o calor humano, aquela quantidade de gente, aquela alegria... e é isso. Num bairro desses assim, acho que na maioria dos bairros periféricos. Tem todos os problemas, todas as dificuldades, mas esse fatos humano, esse calor humano prende muito a gente. Eu, principalmente, sou uma pessoa que não quero sair dali. Se tiver que me mudar, que seja por lá mesmo, mas que fique por lá. Porque a gente sente muito, a gente estranha muito sair de um lugar assim, né? (Lucas Lima em entrevista concedida à autora em 19 de novembro de 2018)

Figura 09 - Moradoras e passantes filmadas no "Live In Jurunas" andando pelo bairro 


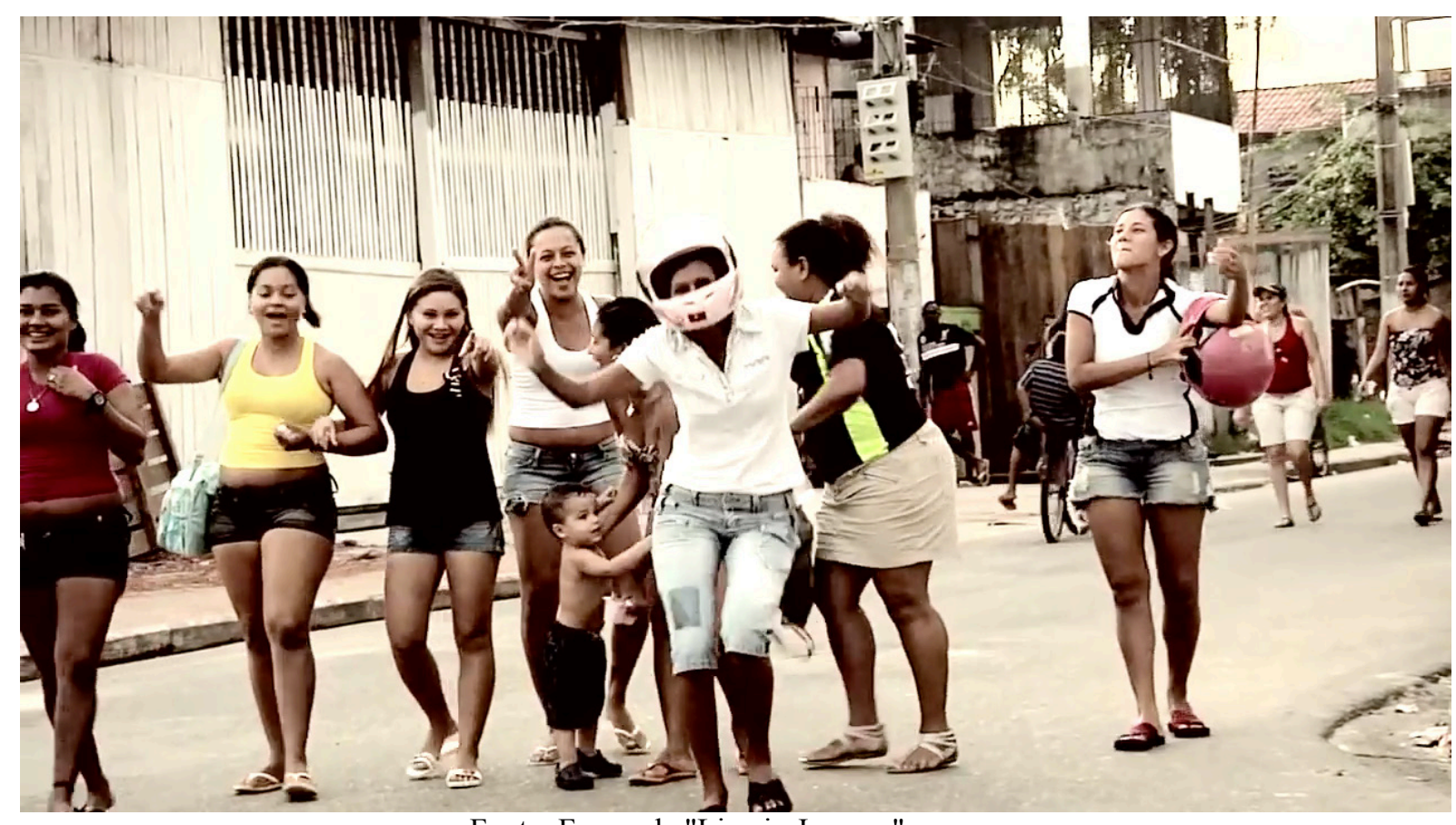

Fonte: Frame de "Live in Jurunas".

Silvia, também moradora do Jurunas, reforçou que o que viu no vídeo é o que cotidianamente encontra em sua vizinhança, quantidade de pessoas nas ruas, a agitação e a familiaridade com as casas.

Eu ia reconhecer porque eu moro aí perto da casa dela, né, eu reconheceria, tipo, a paisagem tudinho, o lugar bem periferia mesmo, chuveiro... festa na rua... colocar mesa, cadeira na rua, é típico do Jurunas. Não tem uma festa, aniversário que não tenha as mesas na rua. Não é aniversário se não tiver isso no Jurunas. (...) Todo dia, todo dia vejo essas coisas. Quando não é na minha casa, é muito nos meus vizinhos. No dia-a-dia, no cotidiano. Tu sair um dia, uma sexta-feira, não tem uma casa com aniversário que não esteja empatando o carro passar, uma passagem, o brega tocando em festa de criança, o brega tá arrochando lá [risos] é... Jurunas é isso. (Silvia Silva em entrevista concedida à autora em 28 de novembro de 2018)

Mais uma vez, o viés documental de Priscilla Brasil espalhou-se para a obra, registrando o entorno e características que são notadas e vividas pelos próprios moradores todos os dias. Nota-se, a partir das falas, que houve a captura dessas experiências que formam a paisagem, o imaginário e o cotidiano do bairro do Jurunas.

No caso da Vila da Barca, os moradores relatam o que lembram daquela época anterior ao início das obras de urbanização, em que haviam majoritariamente palafitas, casas construídas de madeira e sobre a água. Facilmente misturam cenas do vídeo "Devorados" com suas lembranças de infância, como Lucas e Daniel, que foram interlocutores da pesquisa e, também, atuaram no videoclipe como as crianças que brincavam entre tábuas, soltavam pipas e se jogavam no rio. 
Nas idas à Vila da Barca, todas as pessoas com quem falei relataram não conhecer previamente a banda ou consumir heavy metal, mas a produção do "Devorados" faz parte da memória de vários deles. Confirmam a verossimilhança também ao lembrarem da cena de policiais invadindo a localidade, comum àquela época e ainda recorrente hoje em dia. A cantora Sammliz, vocalista da banda Madame Saatan na época dos videoclipes mencionou, em entrevista, o envolvimento que o grupo teve com os moradores, passando a conhecê-los melhor assim como a localidade. Houve uma troca entre artistas e comunidade para a concepção do vídeo.

Figura 10 - Adentrando a Vila da Barca, fotos da autora

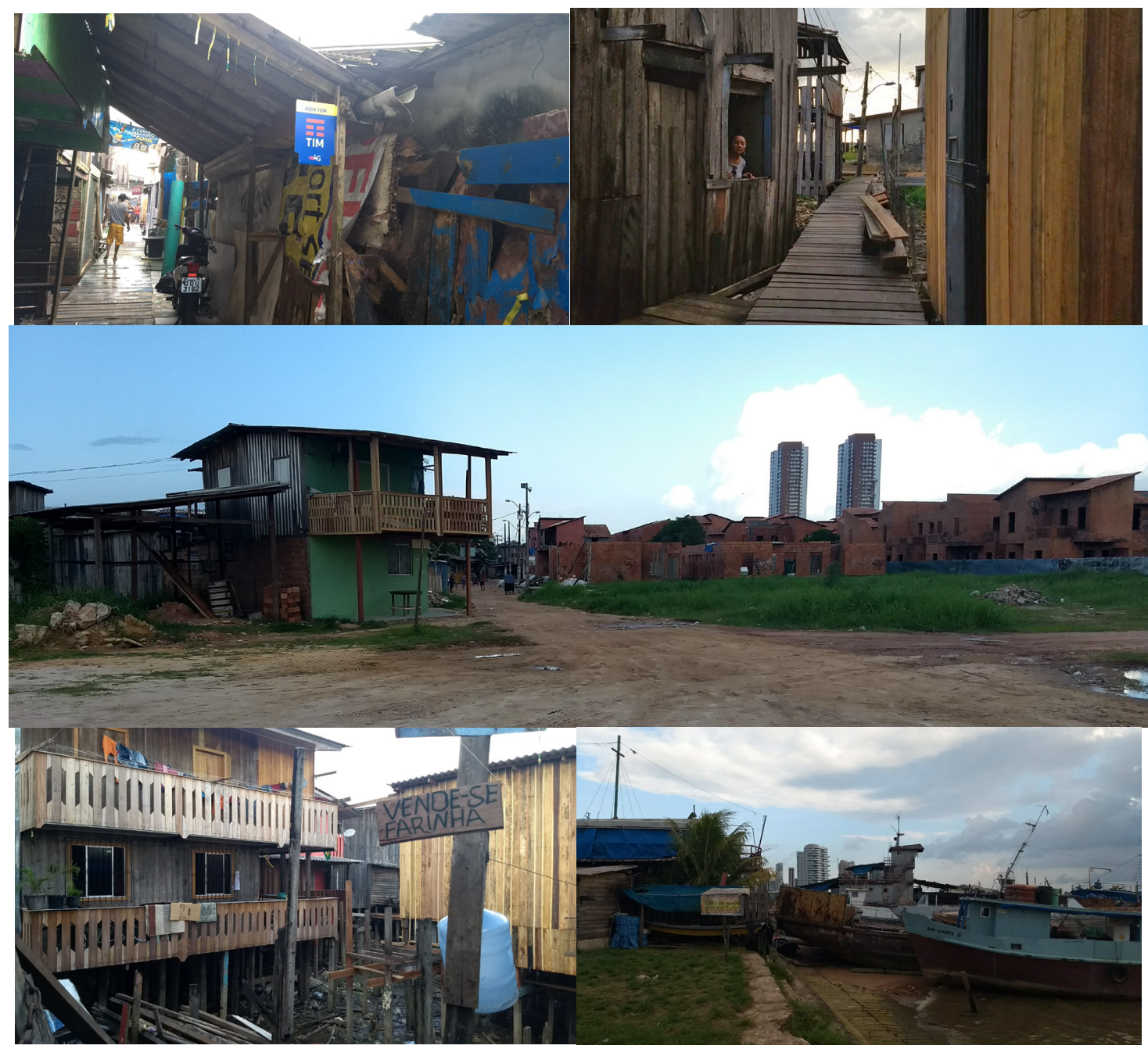

Fonte: Fotos da autora

É inevitável a comparação na fala deles, desta época das filmagens com o período da entrevista. E não é difícil ver o quanto, apesar das mudanças na paisagem, podemos ver a Vila da Barca captada por Priscilla Brasil, com suas sociabilidades características 
(de vizinhos que são família ou se tratam como tal) e as desigualdades, como nas imagens acima, em que se vê barcos, casas de madeira, lixo e, ao fundo prédios enormes e caros localizados no bairro vizinho. Contrastes comuns em uma mesma Belém.

\section{Fronteiras e vizinhanças}

Entre os locais mais falados e estranhezas do que é comumente registrado, os interlocutores desta pesquisa foram unânimes quando perguntados sobre a diferença entre o que é filmado por gente "de dentro" (que conhece a localidade) e produtores externos. Lucas, o morador do Jurunas, e Sammliz, da banda de heavy metal, pontuaram produções recentes de série e curta-metragem, “A Lei” (2018), do canal Space, e o episódio “A Queda do Céu - Aquilo que Os Jovens Chamam de Música - Cap. II” ${ }^{20}$, respectivamente, feitas por equipes externas, que tiveram a capital paraense como locação mas que obtiveram resultados positivos, segundo os mesmos, porque houve interação prévia e pesquisa para conhecer os espaços e contextos que viriam a ser registrados.

Ambas as menções tocam em ponto primordial: o conhecimento (ou desconhecimento) dessa cidade. Conhecemos os espaços pelos quais circulamos, um trecho dos nossos bairros, o caminho para o trabalho. Priscilla Brasil citou os bairros da Batista Campos e Jurunas, um dos bairros mais ricos da cidade e um dos mais populosos, respectivamente, são separados por uma rua fronteiriça que divide dois universos distintos. Na maioria das vezes um desconhece o outro, pois não costuma "passear" pela vizinhança. Assim, sabe-se do bairro do lado pelo jornal local, que cita um quando fala da violência ou o outro, em alguma matéria na praça ou lojas frequentadas por uma dada "elite".

As vendedoras de comida Neide e Marilda, seja no centro comercial da cidade, seja na Avenida Nazaré, relatam, sem esforço, o quanto turistas chegam em Belém esperando conhecer aquilo que viram nas mídias nacionais e internacionais, a gastronomia, as paisagens. Dizem ser benéfico para as vendas de comidas, ervas, as iguarias locais típicas, no entanto, sobre o que é midiatizado, Neide resume: "a gente olhando, a gente que é paraense, a gente não se visualiza ali, entendeu? Na linguagem em si. Mas ele traz o benefício, com certeza, né?”. E assim vários entrevistados listaram novelas, programas e outros tipos de filmagens em que não se viram retratados.

\footnotetext{
${ }^{20}$ Episódio “A Queda do Céu - Aquilo que Os Jovens Chamam de Música -Cap. II”, disponível em: $<$ https://youtu.be/7AkTaiX9lu0> Acesso em 03 dez. 2018.
} 
Carol Matos, que dirigiu vários outros videoclipes de artistas paraenses (como Natália Matos, Felipe Cordeiro e Aíla) além do "Velocidade do Eletro" e hoje mora em São Paulo, diz ver notadamente a diferença entre os olhares:

\begin{abstract}
A pessoa que é de fora sempre vai olhar Belém com olhar de colonizador. Então assim, eles nunca vão poder dizer alguma coisa muito diferente do que já foi dito. (...) Eu me conheço mais do que qualquer pessoa, eu posso falar de mim mais do que ninguém além do olhar do colonizador, de quem tá fora. Então assim, eu acho que a gente tem que aprender a sair dessa casca do colonizador de pensar o quê que as pessoas querem ver, o quê que o colonizador quer ver. (Carol Matos em entrevista concedida à autora em 12 de outubro de 2018)
\end{abstract}

Seja mostrando aquilo que o "colonizador" quer ver ou o que queremos, enquanto amazônidas, mostrar, vemos que ainda há um universo a ser visto mais de perto, dentro dessa gama que ainda é pouco conhecida. A colonialidade veio nítida na fala da diretora e também do jornalista e diretor de videoclipes dentro da TV Cultura Roger Paes, que disse que as pessoas que vêm de fora produzir, apesar do seu elevado nível técnico:

Nem sempre elas conseguem ir no centro, né? No âmago, na alma, sabe? Nem sempre, assim. Acho que muita coisa ainda fica com aquele olhar do colonizador e do exótico, né? E que não existe mais isso. As coisas, depois da internet, juntou todo mundo. Não existe mais, né? Acho que a gente tem que ser antropólogo, mesmo, assim, tem que ter um olhar antropológico pra se aproximar e não achar que ele é exótico e você não é. (Roger Paes em entrevista concedida à autora em 04 de dezembro de 2018)

Bruner (1986) defende não ser possível alcançar o "âmago" do outro, que seria, talvez, a experiência genuína. Mas a tentativa de fazê-lo já é um passo significativo, criando interesses sobre o local e se afastando da repetição dos recursos colonizadores. Um possível caminho para iniciar estas criações de outras percepções sobre cidades amazônidas começaria no olhar para o lado, caminhar nas ruas vizinhas, olhar para o lado e tentar entender os contextos, os costumes, as pessoas que vivem de formas às vezes contrastantes com as nossas. Já existe a tentativa de algumas produções forâneas de pesquisar e investigar seus espaços de interesse, o que reforça que podemos também ter esta iniciativa. 


\section{Considerações finais}

Iniciei essa pesquisa planejando fazer uma investigação através de videoclipes mas, o campo e a busca pela história e produção locais de vídeos musicais me fizeram entender a importância e o quanto o gênero está em expansão na capital paraense. $O$ audiovisual está retomando fôlego em Belém, em especial desde a década de 2010, em que se observa maior acesso à câmeras e dispositivos móveis que facilitam/democratizam a captação de imagem, assim como o acesso à internet, que se popularizou mais que a década anterior. Filma-se mais, consome-se mais.

A partir disto, notei que o belenense se envolve, sim, com o que falam sobre sua cidade, sobre seus costumes. Observa quando filmam no ponto turístico, quando a televisão comete erros ao falar da cidade ou de algum costume local, fica sabendo/comemora quando sabe que seu bairro vai ser mostrado/filmado, tem curiosidade. Belém gosta de se ver, mas ainda se vê pouco. Dentre as mídias, a tradicional televisão ainda é a principal, mas que está sendo rapidamente alcançada por mídias sociais como WhatsApp ou Facebook, por exemplo, em que criação, divulgação e compartilhamento de conteúdos é consideravelmente mais acessível e democrático que alguns outros. As mensagens instantâneas se espalham em alta velocidade.

A cidade está sendo assistida e a cidade está sendo mostrada. Mas há, ainda, um desencontro: o público que assiste, não assiste o que é feito aqui; os produtores que filmam, não são vistos pelo público daqui. A partir das entrevistas é, às vezes, explícito, nas falas de alguns dos interlocutores, o desconhecimento que temos de nós mesmos, enquanto belenenses, enquanto amazônidas. Ainda precisamos olhar para a outra rua, para outros bairros que não sejam os nossos para que possamos apreender um pouco mais sobre esta Belém tão plural e como fazemos para chegar às nossas próprias telas.

Os interlocutores podem não consumir todos os conteúdos ou saber o que é falado sobre a cidade, o estado e a região, mas observam seu cotidiano ou sabem da necessidade de fazê-lo, frente ao que é levado, falado e/ou feito por estrangeiros. Há sentido crítico. A população sabe e quer se ver, também sabe apontar quando não é aquela a sua cotidianidade. 
As 23 pessoas que contribuíram diretamente com suas falas e histórias para esta pesquisa fizeram com que eu entendesse que nos falta exercitar esse olhar sob outras perspectivas. A experiência nos faz ter acesso a várias formas diferentes de "conhecer", formas que podem se aproximar, mas jamais serão iguais. O curioso e a beleza, para mim, estão exatamente nesta não-unidade, na impossibilidade de tornar estes vários em um só, porque são muitos, porque somos muitos. A partir disso que devemos desenvolver pesquisas, olhares, cuidados.

O Nuevo Cine Latinoamericano tem seu papel e influência sobre outras categorias do audiovisual, influenciando a fala sobre si mesmo, seu entorno e suas histórias cotidianas. As vozes dos subalternizados encontram, nas produções culturais, um espaço para se expressar, de modo que o videoclipe, com suas particularidades, consegue atingir públicos e lugares de modo diferente dos demais gêneros do audiovisual. $\mathrm{O}$ contato com os três grupos de interlocutores, espaços diferentes, fez com que emergissem perspectivas que se complementam e que, por vezes, não se tocam, não convergem entre si, o que traz à tona as cotidianidades diferentes e que moldam cada uma destas experiências.

Paisagens se modificam, atividades e interações que ocorrem nos espaços também, as percepções mudam e, com o videoclipe, temos acesso cada vez maior às experiências possíveis dentro da cidade, bem como o registro histórico (seja o que reforça o "oficializado" ou não), que permitem o revisitar de outras épocas, como o "Devorados" na Vila da Barca antes da reurbanização.

Acredito que o que o que mais se destaca são as diversas nuances existentes na mesma cidade, o caráter polissêmico das paisagens urbanas (Silveira, 2009, p. 73) e que ainda são desconhecidas por quem as filma, de modo geral. Isto foi falado por duas das diretoras entrevistadas, mas também foi possível notar quando, já com o recorte desta pesquisa fechado e entrevistas em andamento, tive contato com videoclipes dos gêneros rap e hip hop, também filmados em Belém, nas áreas de periferias, como os do Vila $91^{21}$. Certamente fazem parte de um circuito (Magnani, 2014; Straw, 2006) e contexto

\footnotetext{
${ }^{21}$ Canal no YouTube de rappers do bairro da Terra Firme, que tem por objetivo divulgar seus MC's e suas músicas que contém, dentre outras temáticas, críticas sociais e experiências pessoais: https://www.youtube.com/channel/UC7YpIrTeIxYtx9amgkNiv4w/about
} 
diferentes daqueles nos quais fiz minhas buscas iniciais, revelando que existe esse cenário audiovisual de periferias que estão a se filmar.

Entendi que as imagens exotizadas do paraense ou belemense que se tem hoje se devem às criações tão enraigadas que, ainda que nós mesmos não acreditemos nelas é o que boa parte da população (de dentro e de fora do estado) ainda acessa, é o que está mais disponível. Existem novas linguagens, outras concepções sobre Belém, mas que não alcançam estes públicos que reproduzem discursos estrangeiristas seja por vontade de criar um pertencer mesmo que por meio da caricatura, seja por desconhecimento e/ou viver em contextos outros onde estes diálogos talvez não façam tanto sentido.

A arte contribui para este acesso a outras vivências neste espaço. É a ratificação de que o audiovisual e, portanto, o videoclipe, faz parte dos meios de criação e reprodução de discursos que podem reforçar ou redefinir percepções. Aqui foram mostradas faces diferentes da cidade de Belém, nesta breve amostra de seis videoclipes. No entanto, os que ficaram de fora desde o primeiro recorte mostram a pluralidade de cenários/paisagens, de ritmos, de músicos/bandas/grupos. Logo, acredito que olhar para este tipo de produção que, como falei anteriormente, vem ganhando mais atenção e espaço, por suas especificidades, pode ser importante para entender não somente o (novo) cenário audiovisual local, mas também a forma como esta sociedade está se pensando e se vendo.

\section{REFERÊNCIAS}

BARTH, Friederic. O Guru, o Iniciador e Outras Variações Antropológicas. Rio de Janeiro: Contra Capa. 243p. 2000.

BHABHA, Hommi. O Terceiro Espaço - uma entrevista com Homi Bhabha (Jonathan Rutherford). Revista do Patrimônio Histórico e Artístico Nacional. 24: 34-41. 1996.

BOAS, Franz. Antropologia Cultural. Rio de Janeiro: Zahar. 109p. 2004. 
BRUNER, Edward. Ethnography as narrative In: Turner, V.; Brunner, E. (eds.) The anthropology of experience, University of Illinois Press, 139-158. 1986.

COSTA, S. Desprovincializando a sociologia: a contribuição pós-colonial. Revista Brasileira de Ciências Sociais, 60 (21): 117-134. 2006.

COSTA, Vânia. M. T. 'À sombra da floresta': os sujeitos amazônicos entre estereótipo, invisibilidade e colonialidade no telejornalismo da Rede Globo. Tese de Doutorado. Instituto de Artes e Comunicação Social, Universidade Federal Fluminense, Rio de Janeiro. 2011.

ECKERT, Cornelia; ROCHA, Ana Luiza Carvalho da. Etnografia de rua: estudo de antropologia urbana. $R U A$, Campinas, SP, v. 9, n. 1, p. 101-127, out. 2015. ISSN 21799911. Disponível em:

$<\underline{\text { https://periodicos.sbu.unicamp.br/ojs/index.php/rua/article/view/8640752/8292>. }}$. Acesso em: 31 out. 2018.

CANCLINI, Néstor García. Culturas Hibridas: estratégias para entrar e sair da modernidade. $4^{\mathrm{a}}$ ed. São Paulo: Edusp, 2003.

JANOTTI JÚNIOR, Jeder; SOARES, Thiago. O videoclipe como extensão da canção: apontamentos para análise. Revista Galáxia, n. 15, p. 91-108, jun. 2008. Disponível em: $<$ https://www.researchgate.net/publication/50361616_O videoclipe como_extenso da cano_apontamentos_para_anlise_The_videoclip_as_an_extension_of_music_Points_for analysis $>$. Acesso em 30 out. 2018.

JODELET, Denise. Les représentations sociales. Paris cedex 14, France: Presses Universitaires de France. 2003.

MAGNANI, José Guilherme Cantor. De perto e de dentro: notas para uma etnografia urbana. Rev. bras. Ci. Soc. [online]. 2002, vol.17, n.49, pp.11-29. ISSN 0102-6909. Disponível em: <http://dx.doi.org/10.1590/S0102-69092002000200002>. Acesso em: 18 out. 2018 . 
- O Circuito: proposta de delimitação da categoria. Ponto Urbe [Online], 15 | 2014. Disponível em <http://journals.openedition.org/pontourbe/2041> Acesso em 21 out 2018.

MARCUS, G. Identidades Passadas, Presentes e Emergentes: requisitos para etnografias sobre a modernidade no final do século XX ao nível mundial. Revista de Antropologia 34: 197-221. 1991.

MIGNOLO, W. A colonialidade de cabo a rabo - O hemisfério ocidental no horizonte conceitual da Modernidade. In: LANDER, E. (org.). A colonialidade do saber: eurocentrismo e ciências sociais - Perspectivas latinoamericanas. Buenos Aires: CLACSO. 2005.

OLIVEIRA, Relivaldo. P. Antropologia e Filosofia: experiência e estética no cinema e na literatura da Amazônia. Belém: Ed. UFPa. 214p. 2011.

PACHECO, Agenor S. Cartografia do trabalho na cidade-floresta. Muiraquitã, PPGLIUFAC, v.2, n.1, Jul/Dez, $2013 . \quad$ Disponível em:

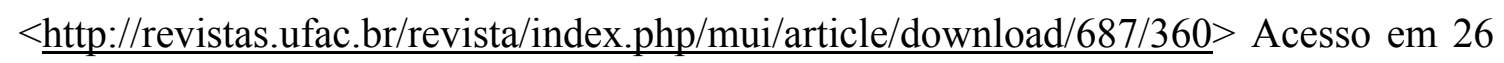
ago 2018.

PIAULT, Marc. Antropologia e Cinema. São Paulo: Unifesp. 432p. 2018.

ROGIN, Michael. Blackface, White Noise. Califórnia, EUA: University of California. 336p. 1996.

SCOTT, Joan. Experience. In: Judith Butler and Joan Scott (eds.) Feminists Theorize the Political. New York: Routledge. pp. 22-40. 1992.

SHOHAT, Ella; STAM, Robert. Crítica da Imagem Eurocêntrica. São Paulo. Cosac Naifi. 536p. 2006 
SILVEIRA, Flávio Leonel Abreu da. A paisagem como fenômeno complexo, reflexões sobre um tema interdisciplinar. In: SILVEIRA, F.L.A. da; CANCELA, C.D.. (Org.). Paisagem e cultura: dinâmicas do patrimônio e da memória na atualidade. 1ed. Belém: Editora da Universidade Federal do Pará, 2009, v.1, p. 71-83.

SOARES, T. Por uma metodologia de análise mediática dos videoclipes: Contribuições da Semiótica da Canção e dos Estudos Culturais. UNIrevista 1(3): 1-11. 2006. Disponível em <http://www.midiaemusica.ufba.br/arquivos/artigos/SOARES1.pdf $>$ Acesso em 28 mai. 2017.

Videoclipe: o elogio da desarmonia. 2012. Disponível em

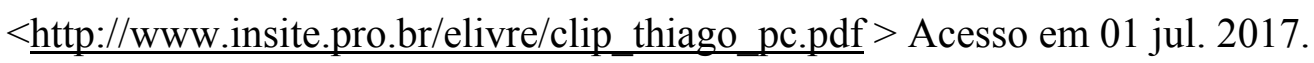

SOUSA, A. C. Arqueologia da paisagem e a potencialidade interpretativa dos espaços sociais. In Habitus 3 (2): 291-300. 2005.

STRAW, Will. Scenes and Sensibilities, 2006.

TADEU, M. A linguagem do videoclipe - Entrevista com Guilherme Bryan. Disponível em $\quad$ http://revistapontocom.org.br/edicoes-anteriores-entrevistas/a-linguagem-dovideoclipe> Acesso em 25 jun. 2016. 2009.

\section{Videoclipes}

AMARANTOS, Gaby. Live In Jurunas. 2011. (31min18s). YouTube. Disponível em: $<$ https://www.youtube.com/playlist?list=PLmVgB5jJHUPAgTFruEJ4S0Sn1Ajfw20ta $>$. Acesso em 13 fev. 2018.

BURNETT, Henry. Oswald Canibal. 2014. (5min17s). YouTube. Disponível em

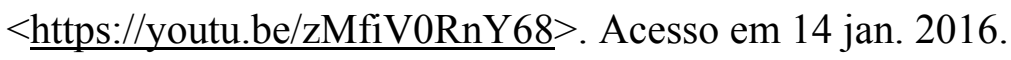


ELETRO, Gang do. Velocidade do Eletro. 2013. (3min03s). Disponível em <https://youtu.be/AGTZ5CBBLso $>$. Acesso em 20 mai. 2017.

ONETE, Dona. No Meio do Pitiú. 2016. (4min21s). YouTube. Disponível em $<$ https://youtu.be/CkFpmCP-R04>. Acesso em 15 dez. 2017.

SAATAN, Madame. Devorados. 2007. (3min53s). YouTube. Disponível em $<$ https://youtu.be/oCXzsldeKS0>. Acesso em 28 mai. de 2017.

Vela. 2009. (4min02s). YouTube. Disponível em
$<$ https://www.youtube.com/watch?v=MjF9zax5d40 $>$. Acesso em 09 jul. 2017.

Recebido: $31 / 01 / 2020$

Aprovado: $15 / 07 / 2020$ 